\title{
A Versatile Human Intestinal Organoid-Derived Epithelial Monolayer Model for the Study of Enteric Pathogens
}

\author{
Kourtney P. Nickerson, ${ }^{\mathrm{a}, \mathrm{b} *}$ Alejandro Llanos-Chea, ${ }^{\mathrm{a}, \mathrm{b} *}$ Laura Ingano, ${ }^{a *}$ Gloria Serena, ${ }^{\mathrm{a}, \mathrm{b} *}$ Alba Miranda-Ribera, ${ }^{\mathrm{a}, \mathrm{b}}$ Meryl Perlman, ${ }^{\mathrm{a}, \mathrm{b} *}$ \\ Rosiane Lima, a Marcelo B. Sztein, ${ }^{c}$ Alessio Fasano, a,b Stefania Senger, ${ }^{\mathrm{a}, \mathrm{b}}$ (D) Christina S. Faherty ${ }^{\mathrm{a}, \mathrm{b}}$ \\ aMucosal Immunology and Biology Research Center, Division of Pediatric Gastroenterology and Nutrition, Massachusetts General Hospital, Boston, Massachusetts, USA \\ bDepartment of Pediatrics, Harvard Medical School, Boston, Massachusetts, USA \\ ‘Center for Vaccine Development and Global Health, Department of Pediatrics, University of Maryland School of Medicine, Baltimore, Maryland, USA
}

Stefania Senger and Christina S. Faherty contributed equally to this work. Order was determined based on additional manuscript preparation tasks.

ABSTRACT Gastrointestinal infections cause significant morbidity and mortality worldwide. The complexity of human biology and limited insights into host-specific infection mechanisms are key barriers to current therapeutic development. Here, we demonstrate that two-dimensional epithelial monolayers derived from human intestinal organoids, combined with in vivo-like bacterial culturing conditions, provide significant advancements for the study of enteropathogens. Monolayers from the terminal ileum, cecum, and ascending colon recapitulated the composition of the gastrointestinal epithelium, in which several techniques were used to detect the presence of enterocytes, mucus-producing goblet cells, and other cell types following differentiation. Importantly, the addition of receptor activator of nuclear factor kappa-B ligand (RANKL) increased the presence of $M$ cells, critical antigen-sampling cells often exploited by enteric pathogens. For infections, bacteria were grown under in vivo-like conditions known to induce virulence. Overall, interesting patterns of tissue tropism and clinical manifestations were observed. Shigella flexneri adhered efficiently to the cecum and colon; however, invasion in the coIon was best following RANKL treatment. Both Salmonella enterica serovars Typhi and Typhimurium displayed different infection patterns, with $S$. Typhimurium causing more destruction of the terminal ileum and $S$. Typhi infecting the cecum more efficiently than the ileum, particularly with regard to adherence. Finally, various pathovars of Escherichia coli validated the model by confirming only adherence was observed with these strains. This work demonstrates that the combination of human-derived tissue with targeted bacterial growth conditions enables powerful analyses of human-specific infections that could lead to important insights into pathogenesis and accelerate future vaccine development.

IMPORTANCE While traditional laboratory techniques and animal models have provided valuable knowledge in discerning virulence mechanisms of enteric pathogens, the complexity of the human gastrointestinal tract has hindered our understanding of physiologically relevant, human-specific interactions; and thus, has significantly delayed successful vaccine development. The human intestinal organoid-derived epithelial monolayer (HIODEM) model closely recapitulates the diverse cell populations of the intestine, allowing for the study of human-specific infections. Differentiation conditions permit the expansion of various cell populations, including $M$ cells that are vital to immune recognition and the establishment of infection by some bacteria. We provide details of reproducible culture methods and infection conditions for the analyses of Shigella, Salmonella, and pathogenic Escherichia coli in which tissue tropism and pathogen-specific infection patterns were detected. This system will be vital for future studies that explore infection
Citation Nickerson KP, Llanos-Chea A, Ingano L, Serena G, Miranda-Ribera A, Perlman M, Lima R, Sztein MB, Fasano A, Senger S,

Faherty CS. 2021. A versatile human intestinal organoid-derived epithelial monolayer model for the study of enteric pathogens. Microbiol Spectr 9:e00003-21. https://doi .org/10.1128/Spectrum.00003-21.

Editor Christina A. Cuomo, Broad Institute

Copyright $\odot 2021$ Nickerson et al. This is an open-access article distributed under the terms of the Creative Commons Attribution 4.0

International license.

Address correspondence to Stefania Senger, ssenger@mgh.harvard.edu (organoid questions), or Christina S. Faherty,

csfaherty@mgh.harvard.edu (organoid infection questions).

* Present address: Kourtney P. Nickerson, Charles River Labs, Wilmington, Massachusetts, USA; Alejandro Llanos-Chea, Division of Pediatric Gastroenterology, Hepatology, and Nutrition, Department of Pediatrics, University of Miami Miller School of Medicine, Miami, Florida, USA; Laura Ingano, Biogen, Cambridge, Massachusetts, USA; Gloria Serena, SQZ Biotechnology, Watertown, Massachusetts, USA; Meryl Perlman, Division of

Gastroenterology, Hepatology, and Nutrition, Department of Pediatrics, Washington University School of Medicine in St. Louis, St. Louis, Missouri, USA.

\#Organoid-derived models provide a robust platform to study \#host-microbe interactions.@ChristinaFaher1 and colleagues share detailed protocols to generate and infect \#gastrointestinal-based models with adherent and invasive \#enteropathogens

Received 16 April 2021

Accepted 20 April 2021

Published 9 June 2021 
conditions, health status, or epigenetic differences and will serve as a novel screening platform for therapeutic development.

KEYWORDS Shigella, Salmonella, Escherichia coli, infection models, human, intestinal, organoid, enteroid, HIODEM, DAPT, RANKL, epithelial monolayer, enterocytes, goblet cells, mucus, $\mathrm{M}$ cells

ver 10 million pediatric deaths occur annually, with over half of these deaths resulting from microbial infection (1). Despite improvements in hygiene, availability of clean water, and access to treatment, few preventive therapies exist and pediatric mortality rates remain high (1-5). Gastrointestinal (GI) pathogens such as Shigella, Salmonella, and Escherichia coli cause diarrhea, dysentery, and even sepsis in some instances (6-10). Many of these pathogens are human restricted, rendering traditional laboratory models insufficient for understanding disease pathologies in humans. In fact, the complexities of human biology coupled with human-specific infection patterns are key barriers to understanding pathogenic mechanisms for successful vaccine development.

To overcome these barriers, we further developed methodology to transition human intestinal stem cells from spheroid cultures into single two-dimensional (2D) cell monolayers that recapitulate the various cell types of the Gl tract (11) and answer critical questions regarding how human-specific pathogens interact with host cells. Here, we present detailed protocols to prepare human intestinal organoid-derived epithelial monolayers (HIODEM) isolated from the ileum, cecum, and ascending colon to test infection with Shigella, Salmonella, and pathogenic E. coli. Monolayers were composed of enterocytes, goblet cells, and other cell types of the various intestinal segments. Through ligand stimulation, the monolayer system was modified to promote expansion of the microfold $(\mathrm{M})$ cell population of the follicle-associated epithelium often exploited by bacterial pathogens to gain access to the epithelium $(12,13)$. Both adherence and invasion of the three Gl segment-derived models were examined with the various pathogens, and the role of $\mathrm{M}$ cells in enteric infections was evaluated for Shigella and Salmonella. We also utilized bacterial growth conditions that replicate the host environment to enhance the virulence of the pathogens prior to infection. In all, this combined methodology has significant potential to transition current research methods into the most human-specific, in vivo-like model to study bacterial pathogenesis and preclinically evaluate therapeutic candidates, potentially leading to paradigm-shifting approaches to vaccine or therapeutic development.

\section{RESULTS}

The HIODEM model for studying enteric pathogenesis. Organoids were derived from tissue biopsy specimens collected from the terminal ileum, cecum, and ascending colon and subcultured for monolayer generation. After isolation and propagation, crypt stem cells were dissociated into single cells and seeded onto transwell inserts. Monolayers reached confluence in 7 to 10 days, during which transepithelial electrical resistance (TEER) was monitored to indicate formation of functional barriers (14). TEER readings were highest in the terminal ileum, averaging $1,010 \pm 112 \Omega \cdot \mathrm{cm}^{2}$ with 0.33 $\mathrm{cm}^{2}$ transwells, whereas cecum monolayers averaged $490 \pm 31 \Omega \cdot \mathrm{cm}^{2}$ and the colon had much lower TEER values, averaging $209 \pm 2.7 \Omega \cdot \mathrm{cm}^{2}$ (Table 1). Following the stabilization of TEER readings, monolayers were treated with the $\gamma$-secretase inhibitor $\mathrm{N}$-[N(3,5-difluorophenacetyl)-L-alanyl]-S-phenylglycine t-butyl ester (DAPT) $(11,15)$, with or without the receptor activator of nuclear factor kappa-B ligand (RANKL) (16) at physiological $(100 \mathrm{ng} / \mathrm{ml})$ or supraphysiological $(500 \mathrm{ng} / \mathrm{ml})$ doses for 24 or $48 \mathrm{~h}$ to ensure differentiation and provide the immune stimulation to induce $M$ cell expression (16-18).

Several methodologies were used to characterize the differentiated monolayers, including flow cytometry, reverse transcription quantitative PCR (RT-qPCR), and transmission electron microscopy (TEM). We focused on ensuring the presence of enterocytes, mucus-producing goblet cells, and M cells, with other cell markers evaluated by RT-qPCR only. First, for flow cytometry, mature monolayers were examined using 
TABLE 1 Average TEER values from this study and reported in the literature ${ }^{a}$

\begin{tabular}{|c|c|c|c|c|}
\hline Cell type/tissue & Origin & Support & $\begin{array}{l}\text { TEER value } \\
\left(\Omega \cdot \mathrm{cm}^{2} \pm \mathrm{SEM}\right)\end{array}$ & $\begin{array}{l}\text { Reference or } \\
\text { source }\end{array}$ \\
\hline Biopsy ileum & Terminal ileum & TW & $1,010 \pm 112$ & This study \\
\hline Biopsy cecum & Cecum & TW & $490 \pm 31$ & This study \\
\hline Biopsy colon & Ascending colon & TW & $209 \pm 2.7$ & This study \\
\hline Caco-2* & $\begin{array}{l}\text { Colorectal } \\
\text { adenocarcinoma }\end{array}$ & TW & 400 & 104 \\
\hline Caco-2 & & TW & 400 & 105 \\
\hline Caco-2 & & TW & 600 & 106 \\
\hline Caco-2 & & TW & 1,000 & 107 \\
\hline Caco-2 & & TW & $900 \pm 23$ & 108 \\
\hline Caco-2/HT-29* & Coculture model & TW & $300-400$ & 109 \\
\hline IPEC-J2* & Porcine jejunum & TW & 1,500 & 110 \\
\hline IPEC-J2 & & TW & $1,000-5,000$ & 111 \\
\hline hiPS-ELC & $\begin{array}{l}\text { Human embryonic } \\
\text { pluripotent stem cells }\end{array}$ & TW & 250 & 105 \\
\hline hiPS-ELC & & TW & 100 & 112 \\
\hline hiPS-ELC & & TW & 900 & 113 \\
\hline hlnEpCs & Small intestine & TW & 1,500 & 113 \\
\hline hlnEpCs & & TW & 400 & 114 \\
\hline FEnS/AEnS & $\begin{array}{l}\text { Fetal intestines and } \\
\text { adult duodenum }\end{array}$ & TW & $400-600$ & 15 \\
\hline AEnS & Duodenum & TW & $600-1,000$ & 71 \\
\hline $\begin{array}{l}\text { hIECs/colonic } \\
\text { fibroblasts }\end{array}$ & Colon & TW & 250 & 115 \\
\hline hiPS-ileal ELC & Ileal & TW & 400 & 11 \\
\hline hiPS-rectal ELC & Rectal & TW & 395 & 11 \\
\hline hIECS & Small intestine & TW & $98.9 \pm 17.5$ & 108 \\
\hline
\end{tabular}

${ }^{a}$ Abbreviations: IPEC, intestinal porcine enterocyte cells; hiPS, human induced pluripotent stem cells; ELC, enterocyte-like cells; hInEpCs, human primary intestinal epithelial cells (commercially available); FEnS, fetalderived enterospheres; AEnS, adult-derived enterospheres; hIEC, human intestinal epithelial cell; TW, transwell. *, cell lines.

antibodies against the transcription factors ESE1 for enterocytes (19), KLF4 for goblet cells (20), and SPIB for M cells (17). The analyses confirmed the presence of the respective cellular markers and enabled us to estimate the cellular populations for each cell type (see Fig. S1 in the supplemental material). Specifically, for the M cell phenotype, RANKL treatment increased the percentage of $\mathrm{SPIB}^{+}$cells relative to the DAPT only treatment across all tissue types with both doses of RANKL for 24 and $48 \mathrm{~h}$ (Fig. 1). Second, to confirm the induction of the SPIB gene with RANKL treatment, we analyzed gene expression at $24 \mathrm{~h}$ following $100 \mathrm{ng} / \mathrm{ml}$ RANKL treatment (Fig. 2). The RT-qPCR analyses revealed significant induction of SPIB expression with the DAPT plus RANKL treatment relative to the DAPT only treatment, with no or minor changes in expression for ESE1, KLF4, and other cellular markers (Fig. 2 and Table 2). It is important to note that expression of ESE1,KLF4, and the other genes was detected under all conditions (data not shown), but the changes in expression were not significantly altered in DAPT plus RANKL treatment compared to DAPT only treatment. Finally, mature monolayers were evaluated by TEM to visualize and confirm the various cell types, monolayer quality, and barrier formation (Fig. 3). Characteristic features of enterocytes, goblet cells, and $M$ cells were visualized, which included the presence of microvilli for enterocytes, secretory granules for goblet cells, and absent or disorganized microvilli with displaced nuclei for M cells (21-23). In all, the data demonstrated that multiple cellular populations were present in the HIODEM models evaluated under the differentiation conditions described above and that RANKL treatment increased the presence of $M$ cells.

Robust Shigella infection requires colonic $\mathbf{M}$ cells. To validate the site of Shigella infection, we analyzed wild-type S. flexneri strain 2457T infection in the terminal ileum-, cecum-, and colon-derived HIODEM by assaying for adherence and invasion. Prior to 

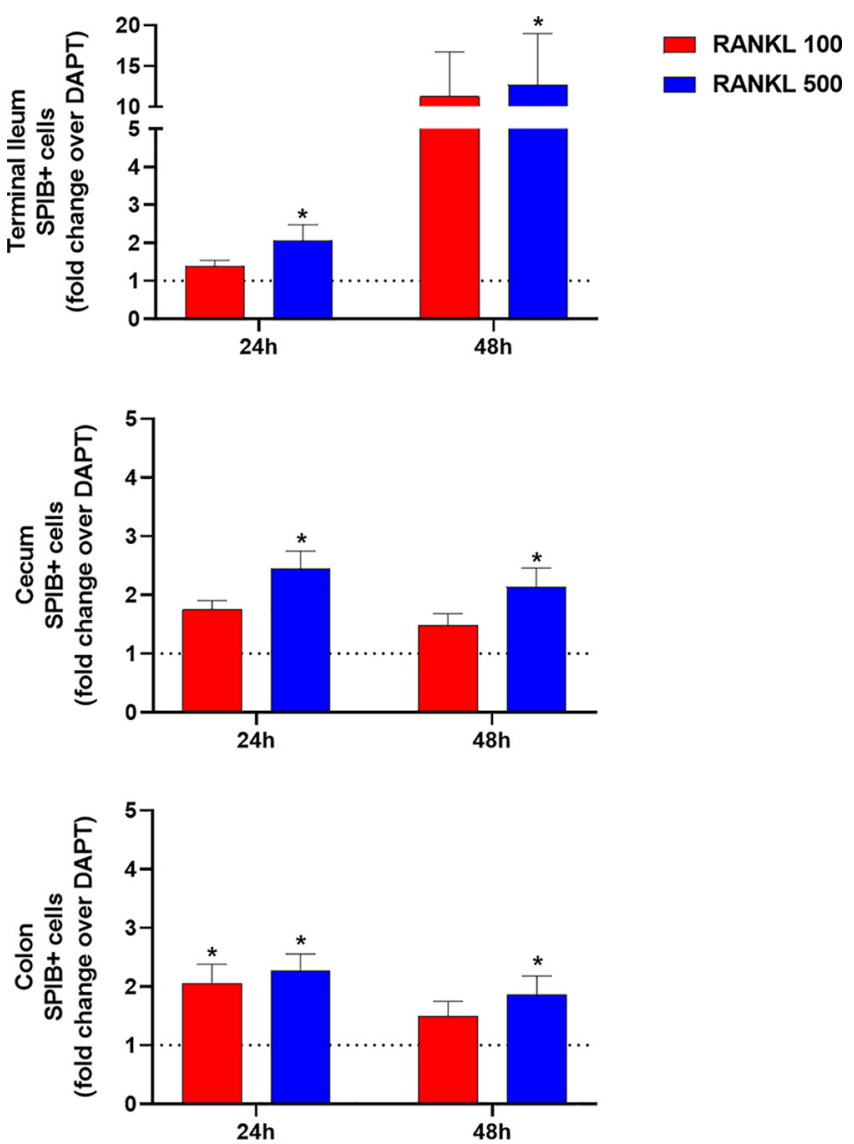

FIG 1 Flow cytometry analyses identify an increase in $\mathrm{SPIB}^{+}$expression following RANKL treatment. The increase in $\mathrm{SPIB}^{+}$expression, which is indicative of $\mathrm{M}$ cell expression, after 24 or $48 \mathrm{~h}$ of RANKL treatment is represented as fold change of $\mathrm{SPIB}^{+}$cells in tissues treated with RANKL (either DAPT + RANKL, $100 \mathrm{ng} / \mathrm{ml}$, red bars, or DAPT + RANKL, $500 \mathrm{ng} / \mathrm{ml}$, blue bars) over the matching tissues treated only with DAPT (represented by the dotted line) for each tissue. Statistical significance was determined by paired Friedman test for the DAPT + RANKL (100 or $500 \mathrm{ng} / \mathrm{ml}$ ) differentiation compared to DAPT only differentiation of the matched originating tissue $\left({ }^{*}, P<0.05\right)$. A total of 4 biological replicate experiments were analyzed for the terminal ileum and cecum, and 6 biological replicates were analyzed for the ascending colon. For each biological sample, an entire 12-well plate was trypsinized, and the cells were pooled into one sample tube for staining and analysis.

infection, S. flexneri was cultured in a combination of bile salts and glucose to replicate small intestinal transit (24-26). For adherence, approximately $5 \%$ of the bacterial inoculum adhered to ileum-derived HIODEM, while the adherence rates for cecum- and colon-derived HIODEM models were nearly triple ( 12 to $15 \%$; Fig. $4 \mathrm{~A})$. For invasion, rates were consistent across the models under most treatments; however, colonderived monolayers differentiated with RANKL to promote the maturation of $M$ cells consistently had a 3-fold increase in invasion (Fig. 4B). A virulence plasmid-cured, noninvasive strain of S. flexneri (strain BS103 [27]) was used as a negative control for invasion and was unable to invade the models under any conditions. Scanning electron microscopy (SEM) of S. flexneri-infected colonic models demonstrated attachment to the apical surface of the cells (Fig. 4C). The S. flexneri adherence pattern occurred throughout the surface of the monolayer. Additionally, shadowed areas beneath adherent bacteria appeared on cells lacking microvilli in the RANKL-treated samples, accompanied by perforations in other parts of the cells. These observations appear to be visual representations of M cell transit required for Shigella invasion (28). Cross-section TEM verified these observations with visualization of invading bacteria localized to $M$ cells (Fig. 4D). Finally, to further validate the model, S. flexneri-infected colon HIODEM 
mRNA expression SPIB 24h

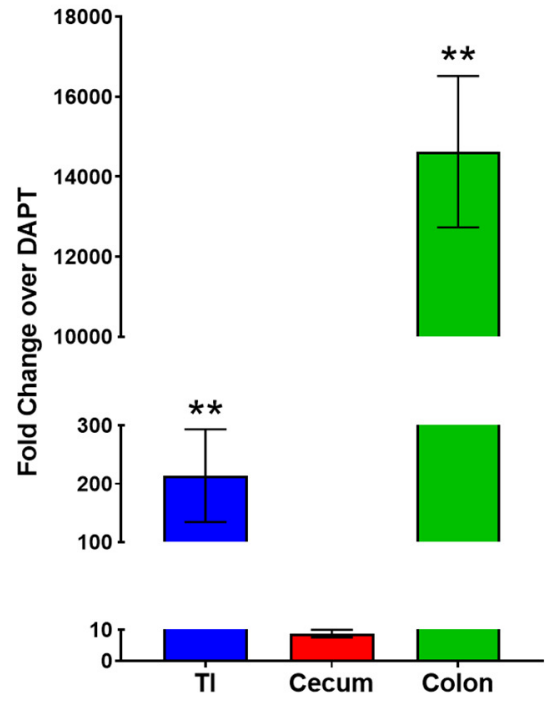

mRNA expression ESE1 24h

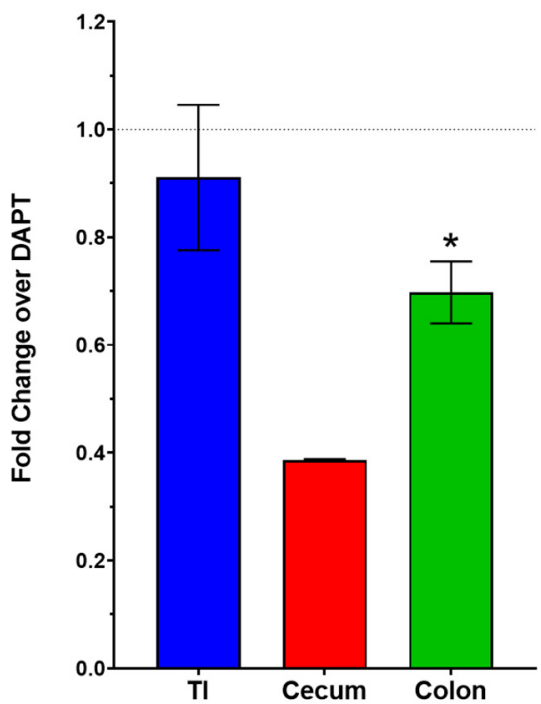

mRNA expression KLF4 24h

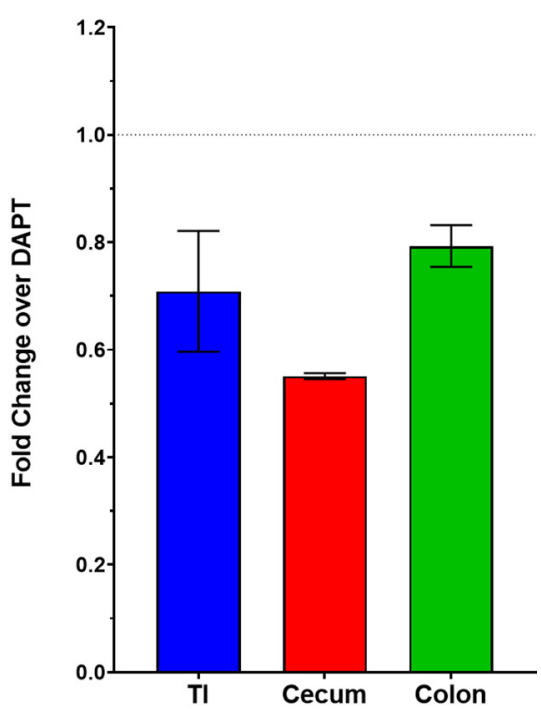

FIG 2 RT-qPCR analyses demonstrate significantly induced SPIB gene expression following RANKL treatment. Gene expression for SPIB, ESE1, and KLF4 was measured following $24 \mathrm{~h}$ of DAPT $+100 \mathrm{ng} / \mathrm{ml}$ RANKL or DAPT only treatment for the terminal ileum (TI, blue, $n=6$ ), cecum (red, $n=3$ ), and colon (green, $n=6$ ). Data are expressed as DAPT + RANKL fold change over the DAPT only treatment, shown as the average fold change \pm standard errors of the means. All data were normalized to expression from the $18 \mathrm{~S}$ housekeeping gene. Statistical significance was determined with the Mann-Whitney unpaired $t$ test of the $\Delta C_{T}$. Data were considered significant at a $P$ value of $<0.05\left({ }^{*},<0.05 ;{ }^{* *},<0.01\right)$. Please note the different $y$ axes for each graph.

monolayers were evaluated for interleukin-8 (IL-8) and lactate dehydrogenase (LDH) release (Fig. S2), since Shigella infection is accompanied by IL-8 secretion $(29,30)$ and inhibition of epithelial cell death $(31,32)$. Significant IL-8 secretion from S. flexneri infection was observed, while mock-treated cells had no detectable levels of IL-8. Additionally, very low levels of LDH were detected for S. flexneri-infected monolayers with no significant difference from mock infection.

Serovar-specific aspects of Salmonella infection are revealed using the HIODEM model. To demonstrate versatility of the HIODEM model, monolayers derived from ileum, cecum, and colon tissue were used to examine adherence and invasion of wildtype Salmonella enterica serovar Typhi strain Ty2 and serovar Typhimurium strain SL1344. Salmonella Typhi infection was more prevalent in the cecum, with a higher rate of adherence and a modest increase in invasion relative to the ileum (Fig. 5A).

TABLE 2 Gene expression analyzed by RT-qPCR in models treated with $100 \mathrm{ng} / \mathrm{ml}$ RANK + DAPT for $24 \mathrm{~h}$

\begin{tabular}{|c|c|c|c|c|c|c|}
\hline \multirow[b]{2}{*}{ Gene $^{a}$} & \multicolumn{2}{|c|}{ Terminal ileum } & \multicolumn{2}{|c|}{ Cecum } & \multicolumn{2}{|l|}{ Colon } \\
\hline & $\mathrm{FC}^{b}$ & $P$ value ${ }^{c}$ & $\mathrm{FC}$ & $P$ value & $\mathrm{FC}$ & $P$ value \\
\hline LRG5 & 1.1 & NS & 4.7 & NS & 0.4 & $<0.005$ \\
\hline$S P I B$ & 213.9 & $<0.005$ & 8.7 & NS & $14,625.1$ & $<0.005$ \\
\hline$K L F 4$ & 0.7 & NS & 0.6 & NS & 0.8 & NS \\
\hline ESE1 & 0.9 & NS & 0.4 & NS & 0.7 & $<0.05$ \\
\hline MUC2 & 2.6 & NS & 0.2 & NS & 1.2 & NS \\
\hline$C G A$ & 0.3 & NS & 0.5 & NS & 1.7 & NS \\
\hline NEUROD & BDL & & $\mathrm{BDL}$ & & 1.2 & NS \\
\hline SPDEF & 0.8 & NS & 0.4 & NS & 0.3 & $<0.005$ \\
\hline SOX9 & 1.2 & NS & 0.3 & NS & 1.3 & $<0.05$ \\
\hline$L Y Z$ & 1.1 & NS & 0.2 & NS & 0.6 & $<0.005$ \\
\hline OCLDN & 1.2 & NS & 0.4 & NS & 1.1 & NS \\
\hline SIM & 1.1 & NS & 0.2 & NS & 1.0 & NS \\
\hline
\end{tabular}

aplease refer to Materials and Methods for information on each gene.

${ }^{b}$ Fold change (FC) reflects the fold change in gene expression in the $100 \mathrm{ng} / \mathrm{ml}$ RANKL + DAPT treatments relative to the DAPT treatment at $24 \mathrm{~h}$. BDL, below detection level. Note that the SPIB expression levels correspond to the data presented in Fig. 2.

cStatistical significance determined with the nonparametric Mann-Whitney test. NS, not significant. 

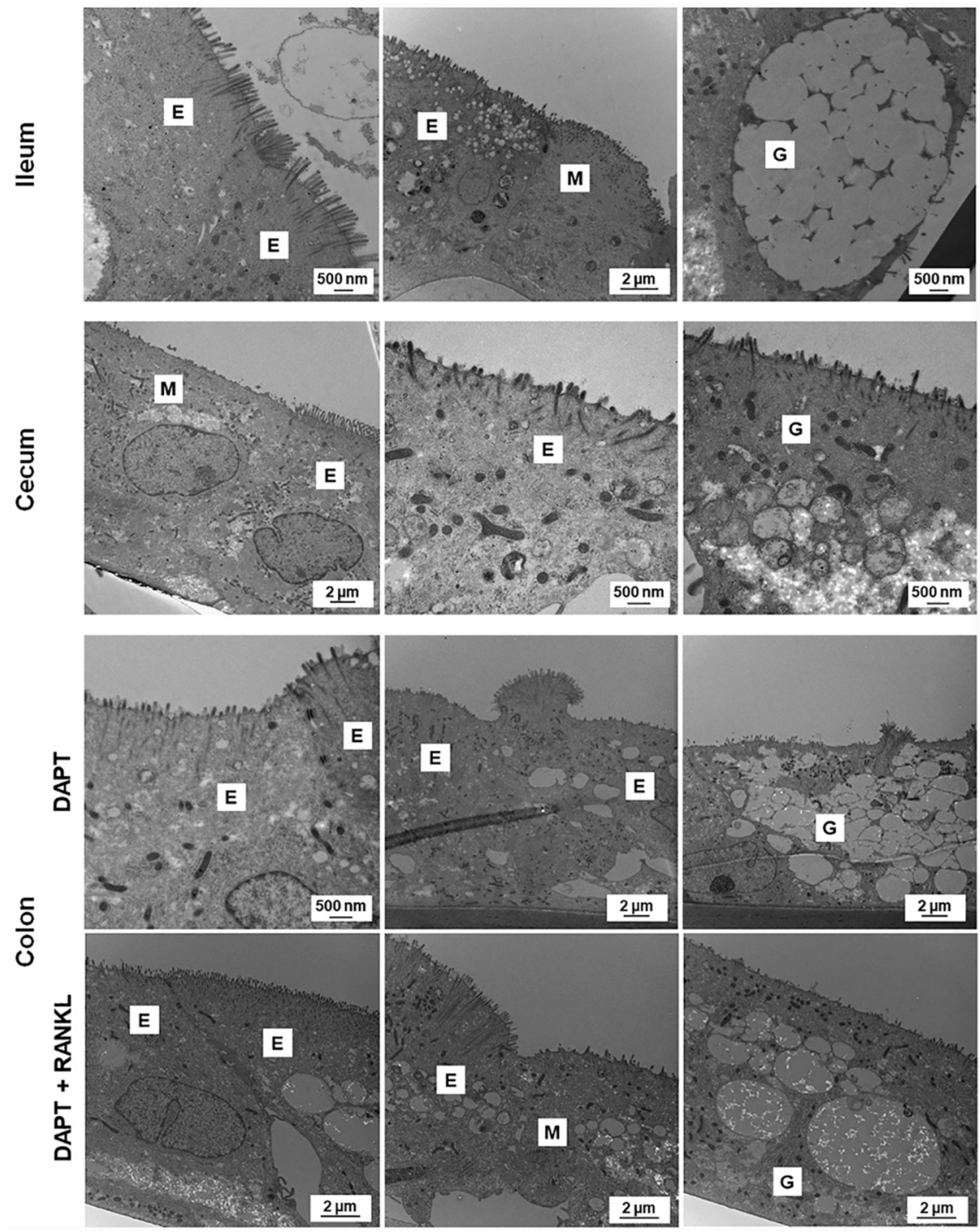

FIG 3 Transmission electron microscopy analysis of the HIODEM models. Mature monolayers derived from the terminal ileum (top), cecum (middle), or colon (bottom) were evaluated by TEM to visualize the cell types present, monolayer quality, and barrier formation. All models displayed characteristic features of enterocytes (E), goblet cells (G), and M cells (M). For the colon, differentiation treatments with DAPT and DAPT + RANKL were compared to visualize the presence of $M$ cells. Magnifications range from $5,000 \times$ to $25,000 \times$, and the corresponding scale bars are provided.

Furthermore, infection of ileum HIODEMs treated with RANKL to promote $M$ cell maturation did not result in a significant increase in intracellular bacteria (Fig. 5B). Transmission electron microscopy of infected HIODEM cells revealed $S$. Typhi associated with the enterocyte surface, remodeled the host cytoskeleton, or was contained within intracellular vesicles (Fig. 5C), while bacterial association with secreted mucus was also observed following immunostaining analysis (Fig. S3). Interestingly, comparison of S. Typhi to S. Typhimurium infections revealed serovar-specific infection patterns (Fig. 5D and E). Unlike S. Typhi, S. Typhimurium infected and replicated robustly within ileum monolayers, with significant destruction of the monolayers revealed upon SEM analysis. Like the TEM, the SEM analysis of the $S$. Typhi-infected monolayers showed bacteria interacting with enterocytes through bacterial surface structures binding to microvilli, with an overall pattern of surface association to intact monolayers. These results both verify our previous findings for 
A.

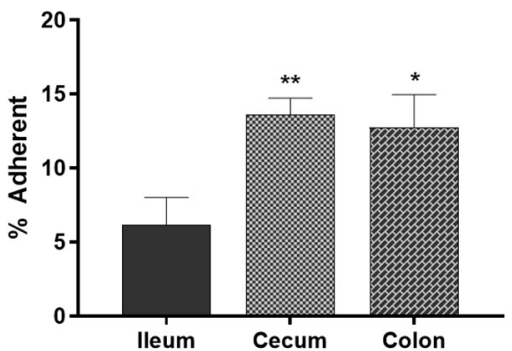

B.

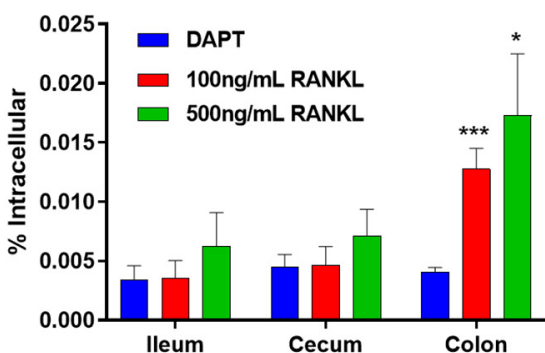

S. flexneri BS103

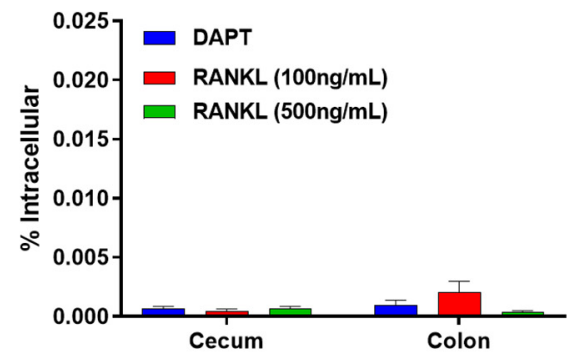

c. DAPT + 100 RANKL
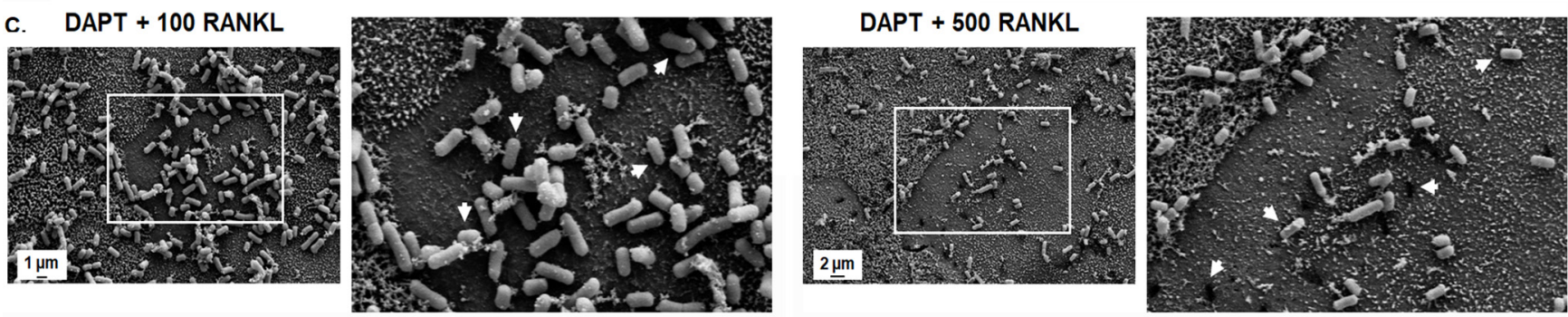

D.

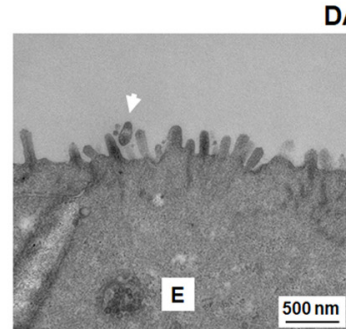

DAPT

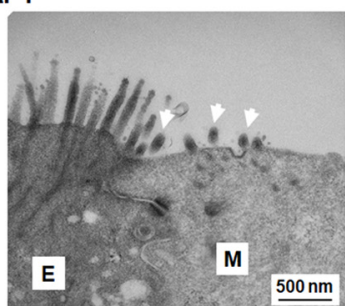

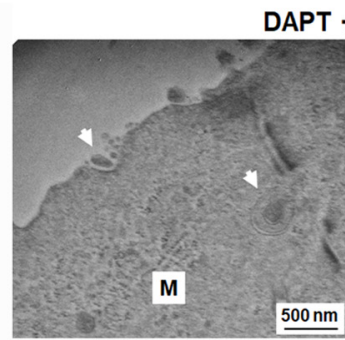

DAPT + RANKL

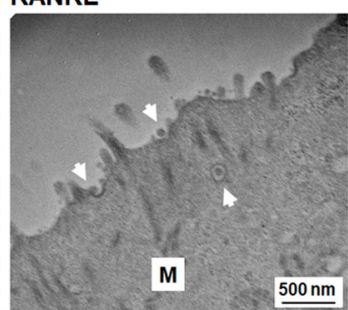

FIG 4 Shigella infection analysis reveals a tissue tropism for the colon. Infection analyses were performed with at least three biological replicates, in which three technical replicates were present for each experiment. Imaging analysis was performed on biological or technical independent samples relative to the plotted infection data. For plotted data, please note the different $y$ axis scales. Statistical significance was determined by the Student's $t$ test of the indicated comparisons $\left({ }^{*}, P<0.05 ;{ }^{* *}, P<0.01 ;{ }^{* *}, P<0.001\right)$. (A) Ileum-, cecum-, and colon-derived HIODEM models were infected with $S$. flexneri strain 2457T, and the percentage of the inoculum adherent to the monolayer surface was determined. S. flexneri was adherent to all three tissue locations with a significant increase in adherence to the cecum- and colon-derived HIODEMs relative to ileum-derived HIODEMs. Statistical analyses compared the ileum adherence rates to the cecum or colon. (B) S. flexneri invasion analysis of the HIODEM models. Colon-derived HIODEMs differentiated with DAPT and RANKL had nearly three times as many intracellular S. flexneri strain 2457T in colonic RANKL-treated HIODEMs. Statistical analyses compared the DAPT-treated monolayers relative to the two DAPT + RANKL treatments for each set of models (ileum, cecum, and colon). The noninvasive strain BS103 did not have significant recovery titers following gentamicin treatment in the cecum or colon HIODEMs despite $\mathrm{M}$ cell differentiation, which validated the invasion data for 2457T. (C) SEM of colon-derived HIODEMs differentiated with DAPT + RANKL at either $100 \mathrm{ng} / \mathrm{ml}$ or $500 \mathrm{ng} / \mathrm{ml}$ concentrations. Bacterial adherence to both enterocytes and M cells, with cell surfaces lacking microvilli, were observed. Magnification ranged from $5,000 \times$ to $7,000 \times$, with $2-\mu \mathrm{m}$ and $1-\mu \mathrm{m}$ scale bars, respectively. Enlarged portions of the images are denoted by the white boxes, and arrows point to areas of various stages of bacterial translocation on the surface of the $\mathrm{M}$ cells. Please note that not all areas are highlighted. (D) Transmission electron micrographs of DAPT and DAPT + RANKLdifferentiated colonic monolayers infected with S. flexneri reveal bacterial association with the apical surface of enterocytes (E) and $M$ cells (M). Areas with bacterial cells at the cellular surface or translocating through $\mathrm{M}$ cells are highlighted by the arrows. Magnification for all images is $50,000 \times$ with 500 -nm scale bars noted.

S. Typhi infection (33) and demonstrate distinctions in serotype-specific infection patterns along different segments of the human Gl tract.

Model validation with pathogenic Escherichia coli. Because the goal of the HIODEM system is to provide the most human-specific physiological model to analyze multiple enteric pathogens, validation of pathogenic $E$. coli infection would help support use of the model for a variety of bacteria. Since Shigella and Salmonella are both invasive pathogens, we decided to test the efficacy of our model on adherent, noninvasive pathogens while also reproducing similar analyses performed by another group (11). Enteropathogenic (EPEC strain 2348/69), enterohemorrhagic (EHEC O157:H7 strain 933), and enteroaggregative (EAEC strain 042) E. coli strains infect different locations of the intestine (i.e., ileum [34], colon [35], and colon [36], respectively). The ability of EPEC, EHEC, and EAEC to adhere or resist gentamicin was determined using organoids derived from the appropriate anatomical site specific to each pathogen in which the 
A.

Adherent S. Typhi
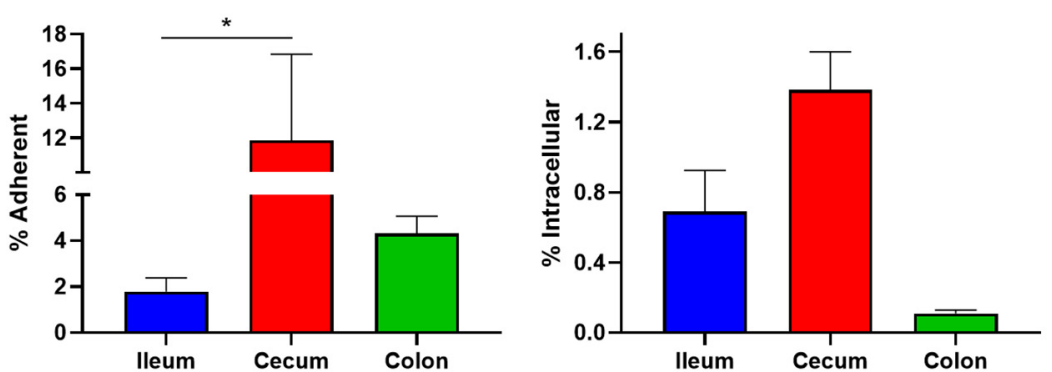

B. Intracellular S. Typhi

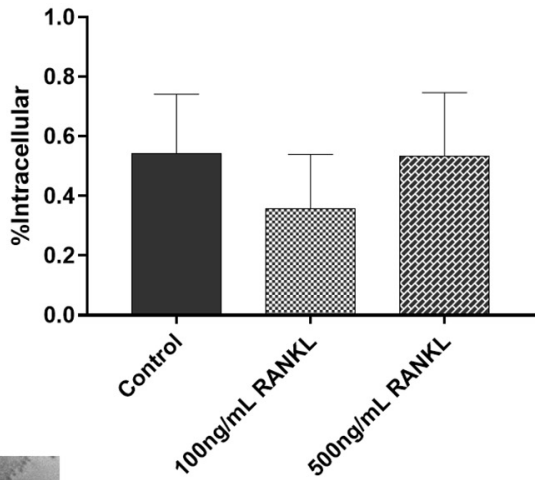

c.
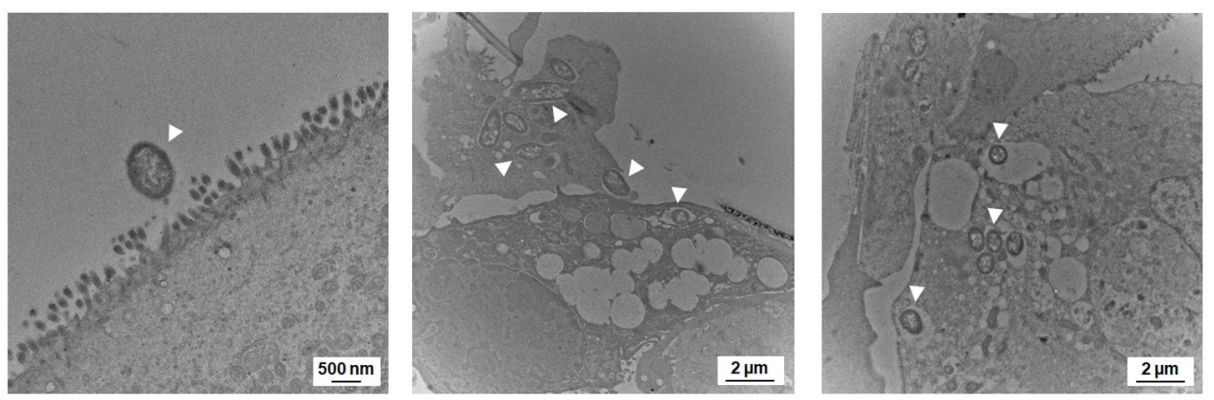

E.

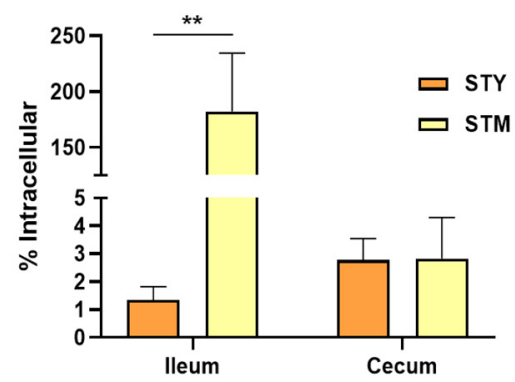

STM

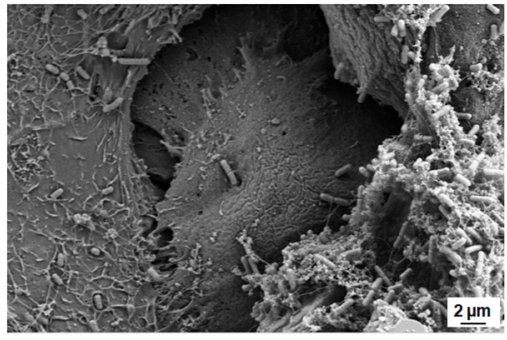

STY

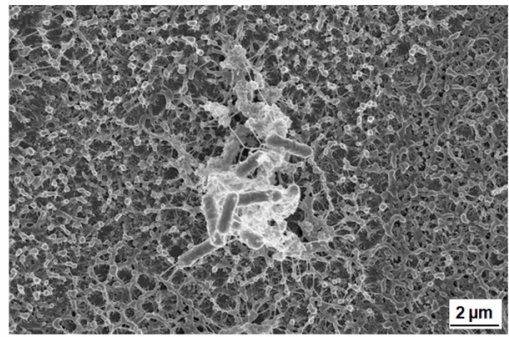

FIG 5 HIODEM model demonstrates Salmonella serovar-specific infection patterns. Infection analyses were performed with at least three biological replicates, in which three technical replicates were present for each experiment. Imaging analysis was performed on biological or technical independent samples relative to the plotted infection data. For plotted data, please note the different $y$ axis scales. Statistical significance was determined by the Student's $t$ test of the indicated comparisons $\left.{ }^{*}, P<0.05 ;{ }^{*}, P<0.01\right)$. (A) Salmonella enteric serovar Typhi strain Ty2 adhered to ileum-, cecum-, and colon-derived HIODEMs, with the greatest rate detected in the cecum monolayers. Invasion was prevalent in the ileum- and cecum-derived HIODEMs, with a modest increase in the cecum monolayers. (B) RANKL treatment of the ileum HIODEMs did not result in significant differences in the rate of invasion. (C) TEM analysis of S. Typhi invasion in the ileum HIODEMs. Magnification ranged from 10,000× to $25,000 \times$, with $2-\mu \mathrm{m}$ and 500 -nm scale bars, respectively. Arrows point to bacteria; note that not all bacterial are highlighted. (D) Salmonella enterica serovar Typhimurium strain SL1344 (STM) preferentially invades ileum HIODEMs at significantly higher rates relative to S. Typhi (STY). (E) Scanning electron micrographs of STM- or STY-infected ileum HIODEMs. STM infection is accompanied by cell rounding and barrier destruction, whereas STY infection maintains barrier function and showed bacterial association with the microvilli of enterocytes. Magnifications range from 7,000x to $14,000 \times$, with $2-\mu \mathrm{m}$ scale bars highlighted for each image. Refer to Fig. S3 for additional images.

HIODEM monolayers were treated with DAPT only. Robust adherence for the three pathogens was detected in colon and ileum organoids; however, recoveries were minimal following gentamicin treatment (Fig. 6A). To confirm these data, confocal immunofluorescence analysis (Fig. 6B), SEM (Fig. 6C), and TEM (Fig. 6D) were performed. EPEC and EHEC adhered to the apical surface of the monolayers in tight association and indications of pedestal formation (37) were present, whereas EAEC adhered in an aggregative fashion (38). Interestingly, we found that the E. coli pathovars displayed a "hotspot" infection pattern that was reproducible and consistent when imaged by various microscopy analyses. These results confirm the efficacy of the HIODEM model in recapitulating known phenotypes associated with pathogenic E. coli (11) and demonstrate the ability of the model to accommodate different pathogens for human cell infection analyses. 
A.

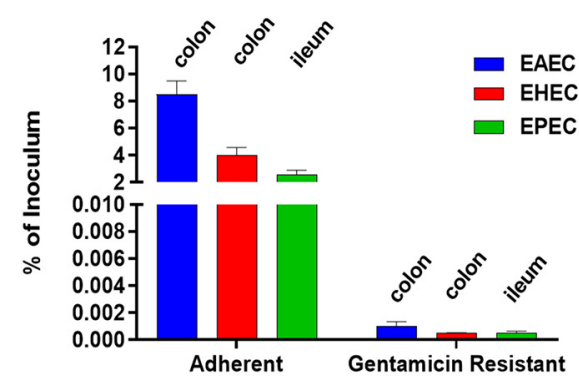

B.

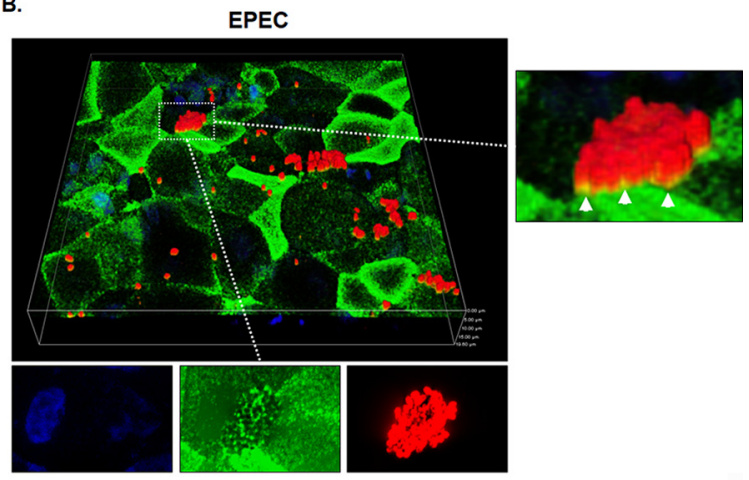

C.

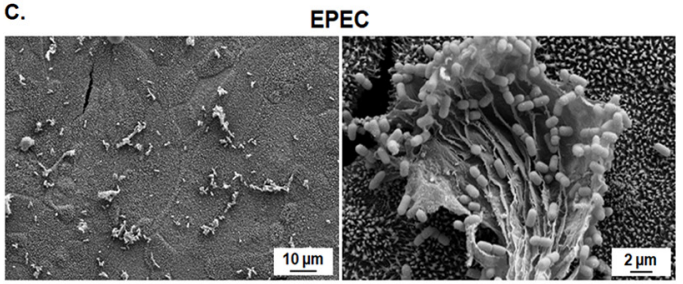

D.

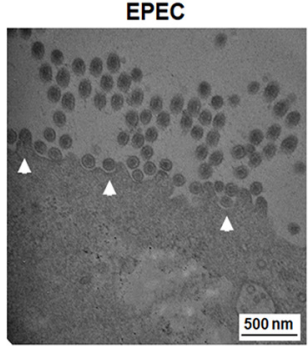

EHEC

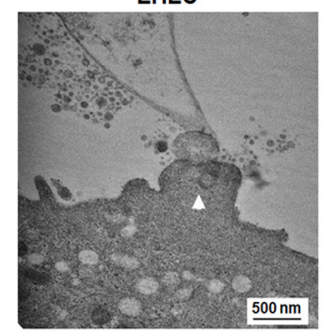

EAEC

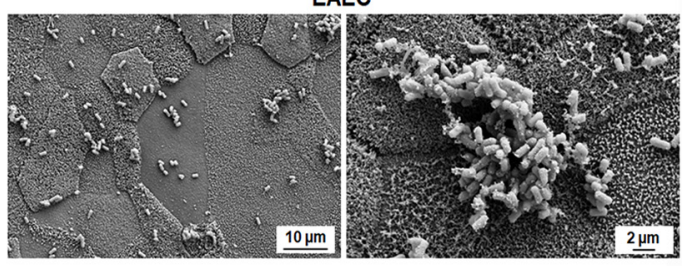

EAEC

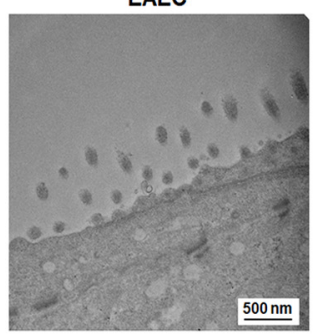

FIG 6 HIODEM supports infection with different Escherichia coli pathovars. (A) Enteroaggregative (EAEC strain 042), enterohemorrhagic (EHEC 0157:H7 strain 933), and enteropathogenic (EPEC strain 2348/69) E. coli adhere to the surface of HIODEMs without significant invasion detected. Colon-derived HIODEMs were used for EHEC and EAEC, while ileum-derived HIODEMs were used for EPEC. (B) Three-dimensional (3D) confocal reconstructions of ileum HIODEM immunostained for actin (green), EPEC (red), and nuclei (blue) show recruitment of actin to the base of adherent bacteria in ileum-derived HIODEM. Magnification of the full image is $40 \times$, with the height and width of the viewing plane at $141.3 \mu \mathrm{m}$ and the depth at $19.6 \mu \mathrm{m}$. The image inset on the right provides a higher resolution of bacterial adherence in which arrows point to areas of bacterial and actin colocalization (yellow signal). The individual channels below the 3D image are top-down views of the same field to further highlight actin colocalization with the bacteria. (C) SEM of EPEC- and EAEC-infected monolayers demonstrate bacterial association with the host cells, aggregation of bacteria, and clusters of bacteria embedded in mucus. Magnifications range from 2,000 $\times$ to $10,000 \times$, with $10-\mu \mathrm{m}$ and 2- $\mu \mathrm{m}$ scale bars, respectively. Ileumderived HIODEM was used for EPEC, and colon-derived HIODEM was used for EAEC. (D) TEM images of infecting EPEC, EHEC, and EAEC. Magnifications range from 50,000 $\times$ to $60,000 \times$, with $500-\mathrm{nm}$ scale bars indicated. White arrows indicate pedestal formation for EPEC and EHEC. Ileum-derived HIODEM was used for EPEC, and colon-derived HIODEMs were used for EHEC and EAEC.

\section{DISCUSSION}

The use of human-derived intestinal organoids to study bacterial pathogenesis has recently increased (39-42). Prior to this advancement, most enteric pathogenesis studies were limited to immortalized cell lines and/or animal models. While traditional models have provided key insights into our understanding of enteric bacterial pathogens, successful vaccine development has been ineffective or limited (43-45). Animal models do not faithfully replicate the human GI tract (46-50), while immortalized cell lines have genetic abnormalities, dysregulated cell signaling pathways, and varied differentiation statuses depending on the cell line and the culturing conditions used (22, 51-53). Thus, there is a significant need to utilize human-specific infection models to improve our understanding of pathogenesis and to facilitate the development of efficacious vaccines against Shigella, Salmonella, and pathogenic E. coli. Intestinal-derived organoid models provide a pluripotent platform to study host-pathogen interactions, 
in which differentiation reagents ensure the presence of multiple cell types of the human epithelium, while regional specificity can be retained by obtaining biopsy specimens from different segments of the GI tract. Given the complexity of the methodology and reagents, we have provided a detailed protocol of our procedure (see the supplemental material) to share with the research community and facilitate hostpathogen studies.

Organoid-derived epithelial monolayer models like the HIODEM have enabled infection analyses by providing a process by which pathogens can directly interact with the apical side of the epithelium $(11,24,33,54-58)$. While three-dimensional organoid systems are available $(40,59-63)$ and "apical-out" organoid systems have been developed (64), HIODEM and other 2D systems offer easily accessible monolayers for pathogenesis studies in which apical and basolateral cytokine secretion profiles and changes in TEER can be examined in a standard transwell culture setting. Similar to traditional polarized models with Caco-2 and T84 cells (65-67), the polarized monolayer of HIODEM allows for a robust infection without need of centrifuging bacteria onto the cells, which is a common practice for infection analyses performed with standard, nonpolarized cell lines (68-70). Finally, the high-throughput nature of the multiwell plate formats enables multiple monolayers to be assayed simultaneously. Possible comparative analyses include various bacterial strains or mutants, infection conditions, ligand treatment, or even screening platforms for therapeutic candidates (23). The possibilities for therapeutic evaluation are amplified by the ability to develop organoids from donors with different genetic backgrounds, environmental exposure, age, disease status, or tissue site. These factors are captured and maintained in the organoid cultures $(15,71,72)$, thereby increasing the potential of the model for patient stratification and precision medicine applications.

For our HIODEM system, medium composition and inhibitors were carefully chosen to maintain the stem cell phenotype during the organoid culturing phase, initiate differentiation when seeded onto monolayers, and promote terminal differentiation in the last $48 \mathrm{~h}$ of monolayer culture prior to use (see the supplemental material). Removal of the A 83-01 inhibitor from the media when shifting from the organoid culture (1:1 + A 83-01 + Y-27632) to the monolayer culture (1:1 + Y-27632) promotes cell attachment to the transwells (S. Senger's observations). As the monolayer culturing progresses, TEER measurements monitor polarization of the models, which will vary depending on the tissue of origin. As noted in Table 1, our TEER values were consistent with published values for other cell-based models on transwell systems in which measurements are highest in the proximal intestine and decrease toward the colon. Passage of fluorescein isothiocyanate (FITC) dextran from the apical medium to the basolateral medium is another method to confirm the TEER readings and integrity of the barrier, as we have previously performed $(15,33,71)$. Finally, transitioning the cells from the monolayer growth medium (apical and basolateral 1:1 + Y-27632) to terminal differentiation medium (apical complete Dulbecco's modified Eagle medium [CDMEM]/ F12 plus DAPT, basolateral 1:1) prior to infection experiments promotes final differentiation, since the factors that maintain stemness are significantly reduced and only present on the basolateral side to replicate in vivo environments (73). Thus, the removal of apical stem cell factors in conjunction with the addition of DAPT is a critical signal that prompts the cells to differentiate and mature into a tissue-like model. It is important to note that each HIODEM model retains the cellular programming from the site of origin, i.e., ileum, cecum, or colon, despite the overall pluripotent state of the stem cells $(11,15,71)$.

One of our goals was to develop a physiologically relevant infection model for Shigella. Given the infection paradigm in which Shigella requires the presence of antigen-sampling $M$ cells to access the basolateral pole for invasion of colonic epithelial cells (28), we sought to utilize a reagent that promotes the differentiation of $M$ cells. We used RANKL based on previous studies $(74,75)$. The RANKL treatment resulted in significant induction of SPIB expression as detected by flow cytometry (Fig. 1) and RT- 
qPCR (Fig. 2) as well as increased appearance of the $M$ cell phenotype upon microscopic examination of the monolayers (Fig. 3), which included displaced nuclei and altered microvilli, ranging from short and disorganized to absent. The induction of SPIB expression and phenotypic appearance were consistent with previous analyses (74-76). The differences in the levels of SPIB expression in each model following RANKL treatment likely reflect the retention of cellular programing from the original biopsy specimen source, as noted above. Importantly, the expression of other cellular markers was not significantly altered with the use of RANKL (Table 2 and Fig. S1), yet important differences between models were noted. For example, the expected higher percentage of goblet cells in the colon-derived models $(77,78)$ was evident at $48 \mathrm{~h}$ of differentiation treatment compared to the ileum- and cecum-derived models (Fig. S1), but the increased percentage in the colon was not significantly altered by RANKL treatment. Thus, our results demonstrate that the cellular populations of the HIODEM models are capable of manipulation by ligand treatment to enable studies focused on specific cell types.

To examine the efficacy of the HIODEM models for pathogenesis, we evaluated Shigella, Salmonella, and pathogenic E. coli infection in models derived from the terminal ileum, cecum, and colon. Overall, we detected tissue tropism, pathogen targeting of specific cell types, and interesting infection dynamics by using models derived from the natural sites of infection. For Shigella (Fig. 4 and Fig. S2), adherence was highest in the cecum and colon, with the rates of both comparable to adherence rates with polarized T84 cells (26). Apical surface adherence was facilitated by Shigella adherence factors expressed under the in vivo-like culture conditions and replicates previous analyses with both the colon and cecum models $(23,24,26)$. Meanwhile, Shigella invasion was the highest in colon following treatment with RANKL to induce the presence of $M$ cells. To confirm our data, we repeated analyses with another patient-derived colon model and detected an approximately 10 -fold increase in recovery, in which the DAPT plus RANKL treatment increased S. flexneri colonic invasion relative to DAPT treatment (data not shown). Overall, both sets of invasion rates were reduced relative to rates seen in nonpolarized HeLa cells (69) or direct basolateral administration of polarized T84 cells $(67,79)$, but these models promote almost complete infection of the host cells and bypass important steps during the infection process. Since the HIODEM model is composed of various cell types, we only expect Shigella infection of the enterocytes. Our results agree with two recent publications using variations of the organoid-derived monolayer model that also verified the colonic tropism and the basolateral entry preference for Shigella invasion $(54,55)$. In this study, microscopy analyses indicated bacterial transit of $\mathrm{M}$ cells, which complements both previous confocal microscopy analyses indicating Shigella translocation of cecum-derived organoids following apical administration (23) and the invasion data rates obtained in the analyses described here. Furthermore, infection with the virulence plasmid-cured strain BS103 resulted in minimal recovery of the bacteria following gentamicin treatment, confirming that wild-type $2457 \mathrm{~T}$ recoveries in the presence of gentamicin were due to bacterial invasion of the model. In all, the bacterial culture conditions, apical administration of the inoculum, and use of RANKL to promote $M$ cell differentiation enables humanspecific conditions to replicate the natural Shigella infection process in the laboratory setting.

In the literature, both $S$. Typhi and S. Typhimurium have been reported to infect the ileum (80-84) but result in differing pathologies, either systemic infection in the case $S$. Typhi or localized gastroenteritis in the case of $S$. Typhimurium. To explore this phenomenon in the HIODEM model, we analyzed infection of both serotypes in the ileum, cecum, and colon (Fig. 5 and Fig. S3). As with the Shigella analyses, we used bacterial culture conditions to induce virulence factor expression. Thus, S. Typhi was cultured with high-salt media and static growth as previously described $(33,85)$, and the same protocol was used for $S$. Typhimurium to maintain similar growth conditions. The infection analyses demonstrated the surprising result that S. Typhi preferentially infected the cecum while $S$. Typhimurium preferentially infected the ileum and caused more 
cellular destruction relative to S. Typhi. Furthermore, treatment of ileum-derived HIODEM monolayers with RANKL to induce $M$ cell differentiation did not enhance $S$. Typhi invasion, which contrasts with S. Typhimurium observations (75) but is consistent with our previous analyses that $S$. Typhi invades human biopsy specimens via the apical surface of enterocytes in which no bacterial associations with $\mathrm{M}$ cells were detected (33). Thus, the HIODEM model reproduced the serovar-specific differences that are expected given the different Gl pathologies associated with each pathogen while also identifying a unique cecum-specific infection pattern for S. Typhi. Reports of S. Typhi infection or damage to the cecum have been documented in the literature. Colonoscopic evaluations of patients with typhoid fever have found intestinal lesions in the terminal ileum in all patients tested, with additional lesions identified by the ileocecal valve and ascending colon (86). Furthermore, perforations of the ileocecum or lower gastrointestinal bleeding associated with the cecal artery have been reported in patients with S. Typhi infection $(87,88)$. Therefore, the HIODEM system offers opportunities to understand key differences between $S$. Typhi and $S$. Typhimurium, which may correlate with genetic differences of the pathogens (89) and/or epigenetic differences in humans.

Finally, the E. coli pathovar analyses validated the HIODEM system as a human-specific model that recapitulates expected infection patterns. Robust infection of the appropriate site of the Gl tract was observed with each pathovar, with comparable rates of adherence and minimal recoveries upon gentamicin treatment to indicate a lack of invasion. The infection patterns and microscopic evaluations are in agreement with previous and recent analyses of organoid monolayer-based systems (11, 56, 57, 72) as well as with established literature regarding actin association/pedestal formation or aggregative adherence patterns $(37,38)$. As with Shigella and Salmonella analyses, the future applications of the HIODEM model system with all E. coli pathotypes are broad and expected to provide key insights into human-specific pathology, including infection analyses in other segments of the Gl tract for each pathovar.

In summary, we have provided reproducible infection analyses of six bacterial pathogens spanning three genera, in which unique observations have already been provided and infection data have been verified with electron microscopic analyses. This model and approach can be applied to additional enteric pathogens or bacteria representing the human microbiota. Coupled with in vivo-like bacterial culture conditions, the HIODEM model offers one of the most human-specific infection analyses that can be performed in the laboratory setting to further our understanding of hostmicrobe interactions and hopefully help lead to the discovery of novel vaccines and therapeutics.

\section{MATERIALS AND METHODS}

Human subject research, IRB approval, and biopsy specimen collection. Human sample collection was approved by Institutional Review Board (IRB) protocols 2014P002001 and 2015P001908 of the Massachusetts General Hospital, Boston, MA. Donor tissue was obtained from consenting patients undergoing medically required colonoscopies or surgical resections, as determined by a licensed physician. All subjects provided written informed consent for samples to be used for research purposes.

Organoid culture and monolayer generation. The protocol has been adapted from previous publications $(11,15,33)$. Please refer to the supplemental material for step-by-step instructions. Briefly, stem cells derived from donor biopsy specimens were maintained in Matrigel culture in a 1:1 mixture of intestinal stem cell medium (ISC) plus L-WRN conditioned medium containing the inhibitors Y-27632 and A 83-01. Cells were seeded at a density of 15,000 cells per Matrigel dome and grown for 7 days in culture. Spheres were trypsinized into a single-cell state, seeded onto polyethylene terephthalate (PET) membrane transwell inserts with a $0.4-\mu \mathrm{m}$ pore size at $1.0 \times 10^{6} \mathrm{cell} / \mathrm{s} / \mathrm{ml}$, and incubated in 1:1 stem cell medium-L-WRN medium at $37^{\circ} \mathrm{C}$ with $5 \% \mathrm{CO}_{2}$. The culture medium was changed every other day until the cultures reached confluence, as determined by TEER monitoring and microscopic observation. Cells grew and matured for 7 to 10 days, at which time the apical and basolateral media were changed and differentiation reagents were applied for either 24 or $48 \mathrm{~h}$ depending on the experiment. Differentiation reagents included $5 \mu \mathrm{M} \gamma$-secretase inhibitor IX (DAPT; Calbiochem) application to the apical surface, which was also combined with 100 or $500 \mathrm{ng} / \mathrm{ml}$ the receptor activator of the NF-KB ligand (RANKL; Peprotech) application to the basolateral media where indicated.

Infection analyses. For information on infection analyses, please refer to the detailed protocols in the supplemental material. 
TEER. To assess paracellular permeability, transwell inserts were monitored using a TEER apparatus (World Precision Instruments, Sarasota, FL) per the manufacturer's instructions $(15,33,66)$.

RT-qPCR analysis. RNA was extracted from monolayers using TRIzol (ThermoFisher) and a Direct-Zol (Zymo) RNA extraction kit. RNA was treated with on-column DNase. RNA was converted to cDNA using Thermo Scientific Maxima first-strand cDNA synthesis kit. Gene expression quantitation was determined using Sybr green (Perfecta), and the CFX96 real-time PCR detection system (Qiagen, Venlo, Netherlands) was used for gene expression analysis. The relative threshold cycle $\left(\Delta \Delta C_{T}\right)$ method was used for assessing gene expression relative to the $18 \mathrm{~S}$ housekeeping reference gene $(15,33)$. Identification of cell type was based on the following genes: LGR5 (90-92) for stem cells, ESE1 (19) and SIM (sucrose isomaltase) (93) for enterocytes, KLF4 (20) and MUC2 (77) for goblet cells, SPIB for M cells (17), CGA (94) and NEUROD (95) for enteroendocrine cells, OCLDN (occludin) $(96,97)$ for barrier formation, and SOX9 $(98,99)$, SPDEF $(98,100)$, and $L Y Z$ (lysozyme) $(101,102)$ for Paneth cells.

Flow cytometry. After differentiation, large transwells (12-well plates) were trypsinized for $10 \mathrm{~min}$. Cells were subsequently resuspended in cDMEM and kept on ice until staining. Cells were fixed, permeabilized, and stained with a flow cytometry fixation and permeabilization buffer kit as directed by the manufacturer. Briefly, cells were washed twice with $1 \times$ phosphate-buffered saline (PBS; Gibco), resuspended in $500 \mu$ l of flow cytometry fixation buffer (R\&D), and incubated for $10 \mathrm{~min}$ at room temperature. Following fixation, cells were permeabilized with $200 \mu \mathrm{l}$ of flow cytometry permeabilization/wash buffer (R\&D) and stained with anti-human ESE1 (Abcam), anti-human KLF4 allophycocyanin-conjugated (R\&D System), and anti-human SPIB (Invitrogen) antibodies by incubating for $45 \mathrm{~min}$ at $4^{\circ} \mathrm{C}$. Afterwards, the excess antibodies were removed by washing the cells with flow cytometry permeabilization/wash buffer and stained with secondary antibodies anti-rabbit IgG1 FITC (Abcam) and anti-mouse IgG2 peridinin chlorophyll protein (BD Bioscience) for $20 \mathrm{~min}$ at $4^{\circ} \mathrm{C}$. Samples were washed again with flow cytometry permeabilization/wash buffer, fixed in 1\% paraformaldehyde in $1 \times$ PBS (Gibco), and acquired with BD FACSCalibur flow cytometer. Analysis was performed with BD Biosciences software. Enterocytes (ESE1 ${ }^{+}$), $\mathrm{M}$ cells $\left(\mathrm{SPIB}^{+}\right)$, and goblet cells $\left(\mathrm{KLF}^{+}\right)$were gated among live cells based on forward and side scatter parameters.

Electron microscopy. For transmission electron microscopy (TEM) analysis, samples were fixed in $2 \%$ paraformaldehyde- $2.5 \%$ glutaraldehyde in $0.1 \mathrm{M}$ sodium cacodylate followed by mounting on grids and imaged using a transmission electron microscope (JEOL, Peabody, MA). For scanning electron microscopy (SEM) analysis, HIODEM monolayers were fixed in $0.5 \times$ Karnovsky fixative (Newcomer Supply) and subsequently stored in $1 \times \mathrm{PBS}$ at $4^{\circ} \mathrm{C}$. All sample processing occurred at the Massachusetts Eye and Ear Infirmary core facility. All SEM imaging was performed at the Harvard University Center for Nanoscale Systems (CNS) using a FESEM Supra55VP microscope.

Cytokine analysis. Quantification of secreted interleukin 8 (IL-8) was conducted using R\&D Systems human CXCL8/IL-8 DuoSet enzyme-linked immunosorbent assay per the manufacturer's instructions (103).

LDH assay. Apical supernatants were assessed for LDH release using a Promega Cytox kit (Promega, Madison, WI) according to the manufacturer's instructions (33).

Immunostaining. For immunostaining, monolayers were fixed in $4 \%$ paraformaldehyde at room temperature for $15 \mathrm{~min}$, followed by storage in $70 \%$ ethanol at $4^{\circ} \mathrm{C}$ until paraffin embedding (33). Embedding and sectioning were performed by the Specialized Histopathology Core of Massachusetts General Hospital. Prior to staining, sections were deparaffinized using xylene with gradual rehydration in decreasing concentrations of ethanol. Sections were blocked using $0.4 \%$ goat and donkey serum in $0.04 \%$ Triton X-100 in PBS. Sections were stained using the antibodies against actin (3700S; Cell Signaling Technologies), Mucin 2 (sc-13312; Santa Cruz Technologies) (33), Salmonella (8209-4006; BioRad), and E. coli (ab137967; kind gift of Deepak V. K. Kumar; Abcam). Fluorescently conjugated secondary monoclonal antibodies (Alexa Fluor 488- and 555-conjugated antibody series against mouse, rabbit, or goat from Life Technologies) were used for detection. Nuclei were counterstained with 6-diamidino-2phenylindole (DAPI). Samples were imaged using a Nikon A1SiR confocal microscope.

\section{SUPPLEMENTAL MATERIAL}

Supplemental material is available online only.

TEXT S1, PDF file, 1.2 MB.

\section{ACKNOWLEDGMENTS}

We gratefully acknowledge Francis Colizzo, James Michael Richter, and Barbara Nath for collection of the samples. Without their technical expertise, these studies would not have been possible. We also thank Bobby Cherayil and Brian Hurly for bacterial strains used in this study, Diane Capen for her expertise and skill in preparing the samples for TEM analysis, Ann Tisdale for her expertise in preparing the SEM samples, and Tim Cavanaugh and the Center for Nanoscale Studies at Harvard University for use of the SEM. We also thank M. Rosaria Fiorentino, members of the Fasano, Fiorentino, and Faherty laboratories, Beth McCormick at the University of Massachusetts Medical School, and the members of the University of Maryland Cooperative Center on Human Immunology $(\mathrm{CCHI})$ for their thoughtful feedback and discussions during the project. 
This work was supported by the National Institute of Allergy and Infectious Diseases grants K22 Al104755 (C.S.F.) and R01-Al036525 (M.B.S.), NIH U19-Al082655 Cooperative Center on Human Immunology (M.B.S. and A.F.), and DHHS U19-Al109776 (Center of Excellence for Translational Research, CETR; M.B.S.). The TEM core is supported by the National Institute of Neurological Disorders and Stroke (P30NS045776). Support for the Philly Dake Electron Microscope Facility was provided by the National Institutes of Health grant 1S10RR023594S10 and by funds from the Dake Family Foundation. The Dana-Farber/Harvard Cancer Center Specialized Histopathology Core is supported, in part, by NCl Cancer Center Support Grant number NIH 5 P30 CA06516. The funders had no role in study design, data collection and analysis, decision to publish, or preparation of the manuscript.

\section{S.S. discloses the following conflicts of interest: PFE, BABA, and KLDO stock holdings.}

\section{REFERENCES}

1. Bryce J, Boschi-Pinto C, Shibuya K, Black RE, WHO Child Health Epidemiology Reference Group. 2005. WHO estimates of the causes of death in children. Lancet 365:1147-1152. https://doi.org/10.1016/S0140-6736(05)71877-8.

2. Lima IF, Havt A, Lima AA. 2015. Update on molecular epidemiology of Shigella infection. Curr Opin Gastroenterol 31:30-37. https://doi.org/10 .1097/MOG.0000000000000136.

3. Kotloff KL, Nataro JP, Blackwelder WC, Nasrin D, Farag TH, Panchalingam S, Wu Y, Sow SO, Sur D, Breiman RF, Faruque AS, Zaidi AK, Saha D, Alonso PL, Tamboura B, Sanogo D, Onwuchekwa U, Manna B, Ramamurthy T, Kanungo S, Ochieng JB, Omore R, Oundo JO, Hossain A, Das SK, Ahmed S, Qureshi S, Quadri F, Adegbola RA, Antonio M, Hossain MJ, Akinsola A, Mandomando I, Nhampossa T, Acacio S, Biswas K, O'Reilly CE, Mintz ED, Berkeley LY, Muhsen K, Sommerfelt H, Robins-Browne RM, Levine MM. 2013. Burden and aetiology of diarrhoeal disease in infants and young children in developing countries (the Global Enteric Multicenter Study, GEMS): a prospective, case-control study. Lancet 382:209-222. https:// doi.org/10.1016/S0140-6736(13)60844-2.

4. GBD Diarrhoeal Diseases Collaborators. 2017. Estimates of global, regional, and national morbidity, mortality, and aetiologies of diarrhoeal diseases: a systematic analysis for the Global Burden of Disease Study 2015. Lancet Infect Dis 17:909-948. https://doi.org/10.1016/S1473-3099(17)30276-1.

5. Kirk MD, Pires SM, Black RE, Caipo M, Crump JA, Devleesschauwer B, Dopfer D, Fazil A, Fischer-Walker CL, Hald T, Hall AJ, Keddy KH, Lake RJ, Lanata CF, Torgerson PR, Havelaar AH, Angulo FJ. 2015. World Health Organization estimates of the global and regional disease burden of 22 foodborne bacterial, protozoal, and viral diseases, 2010: a data synthesis. PLoS Med 12:e1001921. https://doi.org/10.1371/journal.pmed.1001921.

6. Clements A, Young JC, Constantinou N, Frankel G. 2012. Infection strategies of enteric pathogenic Escherichia coli. Gut Microbes 3:71-87. https://doi.org/10.4161/gmic.19182.

7. Azmatullah A, Qamar FN, Thaver D, Zaidi AK, Bhutta ZA. 2015. Systematic review of the global epidemiology, clinical and laboratory profile of enteric fever. J Glob Health 5:020407. https://doi.org/10.7189/jogh.05.020407.

8. Schnupf P, Sansonetti PJ. March 2019. Shigella pathogenesis: new insights through advanced methodologies. Microbiol Spectr https://doi .org/10.1128/microbiolspec.BAl-0023-2019.

9. Wain J, Hendriksen RS, Mikoleit ML, Keddy KH, Ochiai RL. 2015. Typhoid fever. Lancet 385:1136-1145. https://doi.org/10.1016/S0140-6736(13)62708-7.

10. Jajere SM. 2019. A review of Salmonella enterica with particular focus on the pathogenicity and virulence factors, host specificity and antimicrobial resistance including multidrug resistance. Vet World 12:504-521. https://doi.org/10.14202/vetworld.2019.504-521.

11. VanDussen KL, Marinshaw JM, Shaikh N, Miyoshi H, Moon C, Tarr PI, Ciorba MA, Stappenbeck TS. 2015. Development of an enhanced human gastrointestinal epithelial culture system to facilitate patient-based assays. Gut 64:911-920. https://doi.org/10.1136/gutjnl-2013-306651.

12. Man AL, Prieto-Garcia ME, Nicoletti C. 2004. Improving M cell mediated transport across mucosal barriers: do certain bacteria hold the keys? Immunology 113:15-22. https://doi.org/10.1111/j.1365-2567.2004.01964.x.

13. Sansonetti PJ, Phalipon A. 1999. M cells as ports of entry for enteroinvasive pathogens: mechanisms of interaction, consequences for the disease process. Semin Immunol 11:193-203. https://doi.org/10.1006/smim .1999 .0175
14. Srinivasan B, Kolli AR, Esch MB, Abaci HE, Shuler ML, Hickman JJ. 2015 TEER measurement techniques for in vitro barrier model systems. J Lab Autom 20:107-126. https://doi.org/10.1177/2211068214561025.

15. Senger S, Ingano L, Freire R, Anselmo A, Zhu W, Sadreyev R, Walker WA Fasano A. 2018. Human fetal-derived enterospheres provide insights on intestinal development and a novel model to study necrotizing enterocolitis (NEC). Cell Mol Gastroenterol Hepatol 5:549-568. https://doi.org/ 10.1016/j.jcmgh.2018.01.014.

16. Knoop KA, Kumar N, Butler BR, Sakthivel SK, Taylor RT, Nochi T, Akiba $H$, Yagita H, Kiyono H, Williams IR. 2009. RANKL is necessary and sufficient to initiate development of antigen-sampling $\mathrm{M}$ cells in the intestinal epithelium. J Immunol 183:5738-5747. https://doi.org/10.4049/ jimmunol.0901563.

17. Mabbott NA, Donaldson DS, Ohno H, Williams IR, Mahajan A. 2013. Microfold (M) cells: important immunosurveillance posts in the intestinal epithelium. Mucosal Immunol 6:666-677. https://doi.org/10.1038/mi.2013.30.

18. Wood MB, Rios D, Williams IR. 2016. TNF-alpha augments RANKL-dependent intestinal $M$ cell differentiation in enteroid cultures. Am J Physiol Cell Physiol 311:C498-C507. https://doi.org/10.1152/ajpcell.00108.2016.

19. Oettgen $P$, Alani RM, Barcinski MA, Brown L, Akbarali Y, Boltax J, Kunsch C, Munger K, Libermann TA. 1997. Isolation and characterization of a novel epithelium-specific transcription factor, ESE-1, a member of the ets family. Mol Cell Biol 17:4419-4433. https://doi.org/10.1128/mcb.17.8 .4419 .

20. Katz JP, Perreault N, Goldstein BG, Lee CS, Labosky PA, Yang VW Kaestner KH. 2002. The zinc-finger transcription factor Klf4 is required for terminal differentiation of goblet cells in the colon. Development 129:2619-2628.

21. Ahmad T, Gogarty M, Walsh EG, Brayden DJ. 2017. A comparison of three Peyer's patch "M-like" cell culture models: particle uptake, bacterial interaction, and epithelial histology. Eur J Pharm Biopharm 119:426-436. https://doi.org/10.1016/j.ejpb.2017.07.013.

22. Lievin-Le Moal V, Servin AL. 2013. Pathogenesis of human enterovirulent bacteria: lessons from cultured, fully differentiated human colon cancer cell lines. Microbiol Mol Biol Rev 77:380-439. https://doi.org/10.1128/ MMBR.00064-12.

23. Llanos-Chea A, Citorik RJ, Nickerson KP, Ingano L, Serena G, Senger S, Lu TK, Fasano A, Faherty CS. 2019. Bacteriophage therapy testing against Shigella flexneri in a novel human intestinal organoid-derived infection model. J Pediatr Gastroenterol Nutr 68:509-516. https://doi.org/10.1097/ MPG.0000000000002203.

24. Chanin RB, Nickerson KP, Llanos-Chea A, Sistrunk JR, Rasko DA, Kumar DKV, de la Parra J, Auclair JR, Ding J, Li K, Dogiparthi SK, Kusber BJD, Faherty CS. 2019. Shigella flexneri adherence factor expression in. in vivolike conditions. mSphere 4:e00751-19. https://doi.org/10.1128/mSphere .00751-19.

25. Nickerson KP, Chanin RB, Sistrunk JR, Rasko DA, Fink PJ, Barry EM, Nataro JP, Faherty CS. 2017. Analysis of Shigella flexneri resistance, biofilm formation, and transcriptional profile in response to bile salts. Infect Immun 85:e01067-16. https://doi.org/10.1128/IAl.01067-16.

26. Faherty CS, Redman JC, Rasko DA, Barry EM, Nataro JP. 2012. Shigella flexneri effectors OspE1 and OspE2 mediate induced adherence to the colonic epithelium following bile salts exposure. Mol Microbiol 85:107-121. https://doi .org/10.1111/j.1365-2958.2012.08092.x. 
27. Maurelli AT, Blackmon B, Curtiss R, III. 1984. Loss of pigmentation in Shigella flexneri $2 \mathrm{a}$ is correlated with loss of virulence and virulence-associated plasmid. Infect Immun 43:397-401. https://doi.org/10.1128/IAI.43.1 .397-401.1984.

28. Mattock E, Blocker AJ. 2017. How do the virulence factors of Shigella work together to cause disease? Front Cell Infect Microbiol 7:64. https:// doi.org/10.3389/fcimb.2017.00064.

29. Sansonetti PJ, Arondel J, Huerre M, Harada A, Matsushima K. 1999. Interleukin-8 controls bacterial transepithelial translocation at the cost of epithelial destruction in experimental shigellosis. Infect Immun 67:1471-1480. https:// doi.org/10.1128/IAl.67.3.1471-1480.1999.

30. Philpott DJ, Yamaoka S, Israel A, Sansonetti PJ. 2000. Invasive Shigella flexneri activates NF-kappa B through a lipopolysaccharide-dependent innate intracellular response and leads to IL-8 expression in epithelial cells. J Immunol 165:903-914. https://doi.org/10.4049/jimmunol.165.2 .903.

31. Mantis N, Prevost MC, Sansonetti P. 1996. Analysis of epithelial cell stress response during infection by Shigella flexneri. Infect Immun 64:2474-2482. https://doi.org/10.1128/IAI.64.7.2474-2482.1996.

32. Faherty CS, Merrell DS, Semino-Mora C, Dubois A, Ramaswamy AV, Maurelli AT. 2010. Microarray analysis of Shigella flexneri-infected epithelial cells identifies host factors important for apoptosis inhibition. BMC Genomics 11:272. https://doi.org/10.1186/1471-2164-11-272.

33. Nickerson KP, Senger S, Zhang Y, Lima R, Patel S, Ingano L, Flavahan WA, Kumar DKV, Fraser CM, Faherty CS, Sztein MB, Fiorentino M, Fasano A. 2018. Salmonella Typhi colonization provokes extensive transcriptional changes aimed at evading host mucosal immune defense during early infection of human intestinal tissue. EBioMedicine 31:92-96. https://doi .org/10.1016/j.ebiom.2018.04.005.

34. Humphries RM, Armstrong GD. 2010. Sticky situation: localized adherence of enteropathogenic Escherichia coli to the small intestine epithelium. Future Microbiol 5:1645-1661. https://doi.org/10.2217/fmb.10.124.

35. Farfan MJ, Torres AG. 2012. Molecular mechanisms that mediate colonization of Shiga toxin-producing Escherichia coli strains. Infect Immun 80:903-913. https://doi.org/10.1128/IAI.05907-11.

36. Harrington SM, Dudley EG, Nataro JP. 2006. Pathogenesis of enteroaggregative Escherichia coli infection. FEMS Microbiol Lett 254:12-18. https://doi.org/10.1111/j.1574-6968.2005.00005.x.

37. Singh V, Davidson A, Hume PJ, Koronakis V. 2019. Pathogenic Escherichia coli Hijacks GTPase-activated p21-activated kinase for actin pedestal formation. mBio 10:e01876-19. https://doi.org/10.1128/mBio.01876-19.

38. Imuta N, Nishi J, Tokuda K, Fujiyama R, Manago K, Iwashita M, Sarantuya J, Kawano Y. 2008. The Escherichia coli efflux pump TolC promotes aggregation of enteroaggregative E. coli 042. Infect Immun 76:1247-1256. https://doi.org/10.1128/IAI.00758-07.

39. Zachos NC, Kovbasnjuk O, Foulke-Abel J, In J, Blutt SE, de Jonge HR, Estes MK, Donowitz M. 2016. Human enteroids/colonoids and intestinal organoids functionally recapitulate normal intestinal physiology and pathophysiology. J Biol Chem 291:3759-3766. https://doi.org/10.1074/ jbc.R114.635995.

40. Verma S, Senger S, Cherayil BJ, Faherty CS. 2020. Spheres of influence: insights into Salmonella pathogenesis from intestinal organoids. Microorganisms 8:504. https://doi.org/10.3390/microorganisms8040504.

41. Ranganathan S, Smith EM, Foulke-Abel JD, Barry EM. 2020. Research in a time of enteroids and organoids: how the human gut model has transformed the study of enteric bacterial pathogens. Gut Microbes 12:1795492. https://doi.org/10.1080/19490976.2020.1795389.

42. Yin Y, Zhou D. 2018. Organoid and enteroid modeling of Salmonella infection. Front Cell Infect Microbiol 8:102. https://doi.org/10.3389/fcimb .2018.00102.

43. Croxen MA, Law RJ, Scholz R, Keeney KM, Wlodarska M, Finlay BB. 2013. Recent advances in understanding enteric pathogenic Escherichia coli. Clin Microbiol Rev 26:822-880. https://doi.org/10.1128/CMR.00022-13.

44. Crump JA, Sjolund-Karlsson M, Gordon MA, Parry CM. 2015. Epidemiology, clinical presentation, laboratory diagnosis, antimicrobial resistance, and antimicrobial management of invasive Salmonella infections. Clin Microbiol Rev 28:901-937. https://doi.org/10.1128/CMR.00002-15.

45. Puzari M, Sharma M, Chetia P. 2017. Emergence of antibiotic resistant Shigella species: a matter of concern. J Infect Public Health 11:451-454. https://doi.org/10.1016/j.jiph.2017.09.025.

46. Barry EM, Pasetti MF, Sztein MB, Fasano A, Kotloff KL, Levine MM. 2013. Progress and pitfalls in Shigella vaccine research. Nat Rev Gastroenterol Hepatol 10:245-255. https://doi.org/10.1038/nrgastro.2013.12.
47. Higginson EE, Simon R, Tennant SM. 2016. Animal models for salmonellosis: applications in vaccine research. Clin Vaccine Immunol 23:746-756. https://doi.org/10.1128/CVI.00258-16.

48. Pitisuttithum $P$, Islam D, Chamnanchanunt $S$, Ruamsap N, Khantapura $P$, Kaewkungwal J, Kittitrakul C, Luvira V, Dhitavat J, Venkatesan MM, Mason CJ, Bodhidatta L. 2016. A clinical trial of an oral live Shigella sonnei vaccine candidate, WRSS1, in Thai adults. Clin Vaccine Immunol https:// doi.org/10.1128/CVI.00665-15.

49. Gohar A, Abdeltawab NF, Fahmy A, Amin MA. 2016. Development of safe, effective and immunogenic vaccine candidate for diarrheagenic Escherichia coli main pathotypes in a mouse model. BMC Res Notes 9:80. https://doi.org/10.1186/s13104-016-1891-z.

50. Kim YJ, Yeo SG, Park JH, Ko HJ. 2014. Shigella vaccine development: prospective animal models and current status. Curr Pharm Biotechnol 14:903-912. https://doi.org/10.2174/1389201014666131226123900.

51. Finlay BB, Brumell JH. 2000. Salmonella interactions with host cells: in vitro to in vivo. Philos Trans R Soc Lond B Biol Sci 355:623-631. https:// doi.org/10.1098/rstb.2000.0603.

52. Hahn WC. 2002. Immortalization and transformation of human cells. Mol Cells 13:351-361.

53. Noben M, Vanhove W, Arnauts K, Santo Ramalho A, Van Assche G, Vermeire S, Verfaillie C, Ferrante M. 2017. Human intestinal epithelium in a dish: current models for research into gastrointestinal pathophysiology. United Eur Gastroenterol J 5:1073-1081. https://doi.org/10.1177/ 2050640617722903.

54. Koestler BJ, Ward CM, Fisher CR, Rajan A, Maresso AW, Payne SM. 2019. Human intestinal enteroids as a model system of Shigella pathogenesis. Infect Immun 87:e00733-18. https://doi.org/10.1128/IAI.00733-18.

55. Ranganathan S, Doucet M, Grassel CL, Delaine-Elias B, Zachos NC, Barry EM. 2019. Evaluating Shigella flexneri pathogenesis in the human enteroid model. Infect Immun 87:e00740-18. https://doi.org/10.1128/IAI .00740-18.

56. Gonyar LA, Smith RM, Giron JA, Zachos NC, Ruiz-Perez F, Nataro JP. 2020. Aggregative adherence fimbriae II of enteroaggregative Escherichia coli are required for adherence and barrier disruption during infection of human colonoids. Infect Immun 88:e00176-20. https://doi.org/10.1128/ IAl.00176-20.

57. Liu L, Saitz-Rojas W, Smith R, Gonyar L, In JG, Kovbasnjuk O, Zachos NC, Donowitz M, Nataro JP, Ruiz-Perez F. 2020. Mucus layer modeling of human colonoids during infection with enteroaggragative $E$. coli. Sci Rep 10:10533. https://doi.org/10.1038/s41598-020-67104-4.

58. Verma S, Prescott RA, Ingano L, Nickerson KP, Hill E, Faherty CS, Fasano A, Senger S, Cherayil BJ. 2020. The YrbE phospholipid transporter of Salmonella enterica serovar Typhi regulates the expression of flagellin and influences motility, adhesion and induction of epithelial inflammatory responses. Gut Microbes 11:526-538. https://doi.org/10.1080/19490976 .2019.1697593.

59. Honer zu Bentrup K, Ramamurthy R, Ott CM, Emami K, Nelman-Gonzalez M, Wilson JW, Richter EG, Goodwin TJ, Alexander JS, Pierson DL, Pellis N, Buchanan KL, Nickerson CA. 2006. Three-dimensional organotypic models of human colonic epithelium to study the early stages of enteric salmonellosis. Microbes Infect 8:1813-1825. https://doi.org/10.1016/j.micinf.2006.02 .020 .

60. Salerno-Goncalves R, Fasano A, Sztein MB. 2016. Development of a multicellular three-dimensional organotypic model of the human intestinal mucosa grown under microgravity. J Vis Exp 113:54148. https://doi.org/ $10.3791 / 54148$.

61. Salerno-Goncalves R, Fasano A, Sztein MB. 2011. Engineering of a multicellular organotypic model of the human intestinal mucosa. Gastroenterology 141:e18-e20. https://doi.org/10.1053/j.gastro.2011.04.062.

62. Heo I, Dutta D, Schaefer DA, lakobachvili N, Artegiani B, Sachs N, Boonekamp KE, Bowden G, Hendrickx APA, Willems RJL, Peters PJ, Riggs MW, O'Connor R, Clevers H. 2018. Modelling Cryptosporidium infection in human small intestinal and lung organoids. Nat Microbiol 3:814-823. https://doi.org/10.1038/s41564-018-0177-8.

63. Karve SS, Pradhan S, Ward DV, Weiss AA. 2017. Intestinal organoids model human responses to infection by commensal and Shiga toxin producing Escherichia coli. PLoS One 12:e0178966. https://doi.org/10.1371/ journal.pone.0178966.

64. Co JY, Margalef-Catala M, Li X, Mah AT, Kuo CJ, Monack DM, Amieva MR. 2019. Controlling epithelial polarity: a human enteroid model for hostpathogen interactions. Cell Rep 26:2509-2520. https://doi.org/10.1016/j .celrep.2019.01.108. 
65. Fiorentino M, Levine MM, Sztein MB, Fasano A. 2014. Effect of wild-type Shigella species and attenuated Shigella vaccine candidates on small intestinal barrier function, antigen trafficking, and cytokine release. PLoS One 9:e85211. https://doi.org/10.1371/journal.pone.0085211.

66. Fiorentino M, Lammers KM, Levine MM, Sztein MB, Fasano A. 2013. In vitro intestinal mucosal epithelial responses to wild-type Salmonella Typhi and attenuated typhoid vaccines. Front Immunol 4:17. https://doi .org/10.3389/fimmu.2013.00017.

67. McCormick BA, Siber AM, Maurelli AT. 1998. Requirement of the Shigella flexneri virulence plasmid in the ability to induce trafficking of neutrophils across polarized monolayers of the intestinal epithelium. Infect Immun 66:4237-4243. https://doi.org/10.1128/IAI.66.9.4237-4243.1998.

68. Hale TL, Formal SB. 1981. Protein synthesis in HeLa or Henle 407 cells infected with Shigella dysenteriae 1, Shigella flexneri 2a, or Salmonella typhimurium W118. Infect Immun 32:137-144. https://doi.org/10.1128/ IAI.32.1.137-144.1981.

69. Emanuele AA, Adams NE, Chen YC, Maurelli AT, Garcia GA. 2014. Potential novel antibiotics from HTS targeting the virulence-regulating transcription factor, VirF, from Shigella flexneri. J Antibiot 67:379-386. https://doi.org/10.1038/ja.2014.10.

70. Sen A, Leon MA, Palchaudhuri S. 1990. Comparative study of attachment to and invasion of epithelial cell lines by Shigella dysenteriae. Infect Immun 58:2401-2403. https://doi.org/10.1128/IAI.58.7.2401-2403.1990.

71. Freire R, Ingano L, Serena G, Cetinbas M, Anselmo A, Sapone A, Sadreyev RI, Fasano A, Senger S. 2019. Human gut derived-organoids provide model to study gluten response and effects of microbiota-derived molecules in celiac disease. Sci Rep 9:7029. https://doi.org/10.1038/s41598 -019-43426-w.

72. Rajan A, Robertson MJ, Carter HE, Poole NM, Clark JR, Green SI, Criss ZK, Zhao B, Karandikar U, Xing Y, Margalef-Catala M, Jain N, Wilson RL, Bai F, Hyser JM, Petrosino J, Shroyer NF, Blutt SE, Coarfa C, Song X, Prasad BV, Amieva MR, Grande-Allen J, Estes MK, Okhuysen PC, Maresso AW. 2020. Enteroaggregative $E$. coli adherence to human heparan sulfate proteoglycans drives segment and host specific responses to infection. PLoS Pathog 16:e1008851. https://doi.org/10.1371/journal.ppat.1008851.

73. Vanuytsel T, Senger S, Fasano A, Shea-Donohue T. 2013. Major signaling pathways in intestinal stem cells. Biochim Biophys Acta 1830:2410-2426. https://doi.org/10.1016/j.bbagen.2012.08.006.

74. de Lau W, Kujala P, Schneeberger K, Middendorp S, Li VS, Barker N, Martens A, Hofhuis F, DeKoter RP, Peters PJ, Nieuwenhuis E, Clevers H. 2012. Peyer's patch $M$ cells derived from $\operatorname{Lgr} 5(+)$ stem cells require SpiB and are induced by RankL in cultured miniguts. Mol Cell Biol 32:3639-3647. https://doi.org/10.1128/MCB.00434-12.

75. Rouch JD, Scott A, Lei NY, Solorzano-Vargas RS, Wang J, Hanson EM, Kobayashi M, Lewis M, Stelzner MG, Dunn JC, Eckmann L, Martin MG. 2016. Development of functional microfold (M) cells from intestinal stem cells in primary human enteroids. PLoS One 11:e0148216. https://doi .org/10.1371/journal.pone.0148216.

76. Williams IR, Owen RL. 2015. M cells: specialized antigen sampling cells in the follicle-associated epithelium, p 211-229. In Mestecky J, Strober W, Russell MW, Kelsall BL, Cheroutre H, Lambrecht BN (ed), Mucosal immunology, 4th ed. Academic Press, New York, NY. https://doi.org/10.1016/ B978-0-12-415847-4.00013-6.

77. Kim YS, Ho SB. 2010. Intestinal goblet cells and mucins in health and disease: recent insights and progress. Curr Gastroenterol Rep 12:319-330. https://doi.org/10.1007/s11894-010-0131-2.

78. Specian RD, Oliver MG. 1991. Functional biology of intestinal goblet cells. Am J Physiol 260:C183. https://doi.org/10.1152/ajpcell.1991.260.2 .C183.

79. Kohler H, Rodrigues SP, McCormick BA. 2002. Shigella flexneri interactions with the basolateral membrane domain of polarized model intestinal epithelium: role of lipopolysaccharide in cell invasion and in activation of the mitogen-activated protein kinase ERK. Infect Immun 70:1150-1158. https://doi.org/10.1128/iai.70.3.1150-1158.2002.

80. Weinstein DL, O'Neill BL, Hone DM, Metcalf ES. 1998. Differential early interactions between Salmonella enterica serovar Typhi and two other pathogenic Salmonella serovars with intestinal epithelial cells. Infect Immun 66:2310-2318. https://doi.org/10.1128/IAI.66.5.2310-2318.1998.

81. Popoff MY. 1991. Virulence factors of Salmonella: from molecular genetics to diagnostic applications. Bull Acad Natl Med 175:811-821.

82. Rout WR, Formal SB, Dammin GJ, Giannella RA. 1974. Pathophysiology of Salmonella diarrhea in the Rhesus monkey: intestinal transport, morphological and bacteriological studies. Gastroenterology 67:59-70. https:// doi.org/10.1016/S0016-5085(19)32926-9.
83. Giannella RA, Formal SB, Dammin GJ, Collins H. 1973. Pathogenesis of salmonellosis. Studies of fluid secretion, mucosal invasion, and morphologic reaction in the rabbit ileum. J Clin Invest 52:441-453. https://doi .org/10.1172/JCI107201.

84. Parry CM, Hien TT, Dougan G, White NJ, Farrar JJ. 2002. Typhoid fever. N Engl J Med 347:1770-1782. https://doi.org/10.1056/NEJMra020201.

85. Tran QT, Gomez G, Khare S, Lawhon SD, Raffatellu M, Baumler AJ, Ajithdoss D, Dhavala S, Adams LG. 2010. The Salmonella enterica serotype Typhi Vi capsular antigen is expressed after the bacterium enters the ileal mucosa. Infect Immun 78:527-535. https://doi.org/10.1128/IAI .00972-09.

86. Lee JH, Kim JJ, Jung JH, Lee SY, Bae MH, Kim YH, Son HJ, Rhee PL, Rhee JC. 2004. Colonoscopic manifestations of typhoid fever with lower gastrointestinal bleeding. Dig Liver Dis 36:141-146. https://doi.org/10.1016/ j.dld.2003.10.013.

87. Bos WT, Willemsen PJ. 2002. Perforation due to ileocaecal salmonellosis. Acta Chir Belg 102:348-350. https://doi.org/10.1080/00015458.2002 .11679329 .

88. Bhatti JM, Memon Y, Sarfaraz S, Salahuddin N. 2019. An unusual case of extensively drug resistant typhoid fever. Cureus 11:e4664. https://doi .org/10.7759/cureus.4664.

89. Sabbagh SC, Forest CG, Lepage C, Leclerc JM, Daigle F. 2010. So similar, yet so different: uncovering distinctive features in the genomes of Salmonella enterica serovars Typhimurium and Typhi. FEMS Microbiol Lett 305:1-13. https://doi.org/10.1111/j.1574-6968.2010.01904.x.

90. Barker N, van Es JH, Kuipers J, Kujala P, van den Born M, Cozijnsen M, Haegebarth A, Korving J, Begthel H, Peters PJ, Clevers H. 2007. Identification of stem cells in small intestine and colon by marker gene Lgr5. Nature 449:1003-1007. https://doi.org/10.1038/nature06196.

91. VanDussen KL, Sonnek NM, Stappenbeck TS. 2019. L-WRN conditioned medium for gastrointestinal epithelial stem cell culture shows replicable batch-to-batch activity levels across multiple research teams. Stem Cell Res 37:101430. https://doi.org/10.1016/j.scr.2019.101430.

92. Liu R, Li H, Cai J, Wei Q, Han X. 2019. Lgr5(+) intestinal stem cell sorting and organoid culture. Animal Model Exp Med 2:132-135. https://doi .org/10.1002/ame2.12057.

93. Watson CL, Mahe MM, Munera J, Howell JC, Sundaram N, Poling HM, Schweitzer JI, Vallance JE, Mayhew CN, Sun Y, Grabowski G, Finkbeiner SR, Spence JR, Shroyer NF, Wells JM, Helmrath MA. 2014. An in vivo model of human small intestine using pluripotent stem cells. Nat Med 20:1310-1314. https://doi.org/10.1038/nm.3737.

94. Chang-Graham AL, Danhof HA, Engevik MA, Tomaro-Duchesneau C, Karandikar UC, Estes MK, Versalovic J, Britton RA, Hyser JM. 2019. Human intestinal enteroids with inducible neurogenin-3 expression as a novel model of gut hormone secretion. Cell Mol Gastroenterol Hepatol 8:209-229. https://doi.org/10.1016/j.jcmgh.2019.04.010.

95. Li HJ, Ray SK, Singh NK, Johnston B, Leiter AB. 2011. Basic helix-loop-helix transcription factors and enteroendocrine cell differentiation. Diabetes Obes Metab 13(Suppl 1):5-12. https://doi.org/10.1111/j.1463-1326.2011 .01438.x.

96. Furuse $M$, Hirase $T$, Itoh M, Nagafuchi A, Yonemura S, Tsukita S, Tsukita S. 1993. Occludin: a novel integral membrane protein localizing at tight junctions. J Cell Biol 123:1777-1788. https://doi.org/10.1083/jcb.123.6 .1777 .

97. Harrer A, Bucker R, Boehm M, Zarzecka U, Tegtmeyer N, Sticht H, Schulzke JD, Backert S. 2019. Campylobacter jejuni enters gut epithelial cells and impairs intestinal barrier function through cleavage of occludin by serine protease HtrA. Gut Pathog 11:4. https://doi.org/10.1186/s13099-019-0283-z.

98. Stappenbeck TS. 2009. Paneth cell development, differentiation, and function: new molecular cues. Gastroenterology 137:30-33. https://doi .org/10.1053/j.gastro.2009.05.013.

99. Bastide P, Darido C, Pannequin J, Kist R, Robine S, Marty-Double C, Bibeau F, Scherer G, Joubert D, Hollande F, Blache P, Jay P. 2007. Sox9 regulates cell proliferation and is required for Paneth cell differentiation in the intestinal epithelium. J Cell Biol 178:635-648. https://doi.org/10 .1083/jcb.200704152.

100. Gregorieff A, Stange DE, Kujala P, Begthel H, van den Born M, Korving J, Peters PJ, Clevers H. 2009. The ets-domain transcription factor Spdef promotes maturation of goblet and Paneth cells in the intestinal epithelium. Gastroenterology 137:1333-1345. https://doi.org/10.1053/j.gastro .2009.06.044.

101. Peeters T, Vantrappen G. 1975. The Paneth cell: a source of intestinal lysozyme. Gut 16:553-558. https://doi.org/10.1136/gut.16.7.553. 
102. Porter EM, Bevins CL, Ghosh D, Ganz T. 2002. The multifaceted Paneth cell. Cell Mol Life Sci 59:156-170. https://doi.org/10.1007/s00018-002 $-8412-z$.

103. Faherty CS, Wu T, Morris CR, Grassel CL, Rasko DA, Harper JM, SheaDonohue T, Fasano A, Barry EM. 2016. The synthesis of OspD3 (ShET2) in Shigella flexneri is independent of OspC1. Gut Microbes 7:486-502. https://doi.org/10.1080/19490976.2016.1239682.

104. Santos PS, Caria CRP, Gotardo EMF, Ribeiro ML, Pedrazzoli J, Gambero A. 2018. Artificial sweetener saccharin disrupts intestinal epithelial cells' barrier function in vitro. Food Funct 9:3815-3822. https://doi.org/10 $.1039 / \mathrm{c} 8 \mathrm{fo} 00883 \mathrm{c}$.

105. Ozawa T, Takayama K, Okamoto R, Negoro R, Sakurai F, Tachibana M Kawabata K, Mizuguchi H. 2015. Generation of enterocyte-like cells from human induced pluripotent stem cells for drug absorption and metabolism studies in human small intestine. Sci Rep 5:16479. https://doi.org/ $10.1038 /$ srep 16479 .

106. Kowapradit J, Opanasopit $\mathrm{P}$, Ngawhirunpat T, Rojanarata T, Ruktanonchai U, Sajomsang W. 2010. Methylated N-(4-N,N-dimethylaminocinnamyl) chitosan enhances paracellular permeability across Caco-2 cells. Drug Deliv 17:301-312. https://doi.org/10.3109/10717541003706273.

107. Man AL, Bertelli E, Rentini S, Regoli M, Briars G, Marini M, Watson AJ, Nicoletti C. 2015. Age-associated modifications of intestinal permeability and innate immunity in human small intestine. Clin Sci 129:515-527. https://doi.org/10.1042/CS20150046.

108. Takenaka T, Harada N, Kuze J, Chiba M, Iwao T, Matsunaga T. 2014. Human small intestinal epithelial cells differentiated from adult intestinal stem cells as a novel system for predicting oral drug absorption in humans. Drug Metab Dispos 42:1947-1954. https://doi.org/10.1124/dmd.114.059493.
109. Garcia J, Fernandez-Blanco A, Teixido M, Sanchez-Navarro M, Giralt E. 2018. D-Polyarginine lipopeptides as intestinal permeation enhancers. ChemMedChem 13:2045-2052. https://doi.org/10.1002/cmdc.201800428.

110. Yu H, Ding X, Shang L, Zeng X, Liu H, Li N, Huang S, Wang Y, Wang G, Cai S, Chen M, Levesque CL, Johnston LJ, Qiao S. 2018. Protective ability of biogenic antimicrobial peptide microcin J25 against enterotoxigenic Escherichia coli-induced intestinal epithelial dysfunction and inflammatory responses IPEC-J2 cells. Front Cell Infect Microbiol 8:242. https://do .org/10.3389/fcimb.2018.00242.

111. Wang J, Huang N, Xiong J, Wei H, Jiang S, Peng J. 2018. Caprylic acid and nonanoic acid upregulate endogenous host defense peptides to enhance intestinal epithelial immunological barrier function via histone deacetylase inhibition. Int Immunopharmacol 65:303-311. https://do .org/10.1016/j.intimp.2018.10.022.

112. Kodama N, Iwao T, Katano T, Ohta K, Yuasa H, Matsunaga T. 2016. Characteristic analysis of intestinal transport in enterocyte-like cells differentiated from human induced pluripotent stem cells. Drug Metab Dispos 44:0. https://doi.org/10.1124/dmd.116.069336.

113. Kauffman AL, Gyurdieva AV, Mabus JR, Ferguson C, Yan Z, Hornby PJ. 2013. Alternative functional in vitro models of human intestinal epithelia. Front Pharmacol 4:79. https://doi.org/10.3389/fphar.2013.00079.

114. Eaton AD, Zimmermann C, Delaney B, Hurley BP. 2017. Primary human polarized small intestinal epithelial barriers respond differently to a hazardous and an innocuous protein. Food Chem Toxicol 106:70-77. https://doi.org/10.1016/j.fct.2017.05.038.

115. Chen HJ, Miller P, Shuler ML. 2018. A pumpless body-on-a-chip model using a primary culture of human intestinal cells and a 3D culture of liver cells. Lab Chip 18:2036-2046. https://doi.org/10.1039/c8lc00111a. 